\title{
Challenges for REDD+ in Indonesia: a case study of three project sites
}

\author{
Ashley M. Enrici ${ }^{1}$ and Klaus Hubacek ${ }^{2}$
}

\begin{abstract}
Reducing Emissions from Deforestation and forest Degradation (REDD+) is a global initiative aimed at curbing carbon emissions from forest cover change. Indonesia, one of the most biodiverse places on the planet with the third largest extent of tropical forest, has been extensively involved in REDD+. Despite commitments from the government of Indonesia and the international community, the deforestation rate has not stabilized or decreased in the years since REDD+'s introduction in 2007. As of 2012, it was arguably the highest in the world. Although there is an extensive body of literature on REDD+, the need for grounded observations from the field could clarify existing challenges and inform future pursuits. We present the results of a case study of three REDD+ project sites to identify important criteria at the root of success or failure: finance, community, boundary enforcement, monitoring, and outcomes of attempted carbon sequestration and biodiversity preservation. Challenges identified for each criteria include a lack of sufficient funding opportunities, inability to enforce boundaries due to corruption, and lack of a solid plan for involving communities. Carbon sequestration and biodiversity preservation results were mixed because of a lack of monitoring and problems with encroachment. We argue that changes must be made to Indonesian policy to help enable enforcement of project boundaries, monitoring technologies should be utilized, and stakeholders, particularly at the national level, need to address some of the challenges discussed to achieve effective REDD+ outcomes in the future.
\end{abstract}

Key Words: forest carbon; forest management; Indonesia; REDD+

\section{INTRODUCTION}

The United Nation's (UN) Reducing Emissions from Deforestation and forest Degradation (REDD) program has been introduced in over 29 countries around the world, with financial and logistical support from many other international actors and institutions. It was developed initially as a way to reduce carbon emissions by providing financial support to developing nations for carbon sequestration resulting from reduced deforestation and forest degradation, and later evolved to include cobenefits to carbon sequestration, such as biodiversity and strengthening indigenous community rights (REDD+). The design of support distribution and project implementation are influenced by a country's forest cover, governance scenario, stakeholder relations, and funding contexts (Holloway and Giandomenico 2009). Skepticism and doubts about REDD+ have developed because of numerous challenges that have arisen with implementation of such a complex and involved undertaking (Edwards et al. 2012, Mabele and Scheba 2016). This research and other accounts (Sunderlin et al. 2014a) even indicated that challenges and negative attitudes toward REDD+ are problematic for the program to the extent that some stakeholders have disassociated from the label of REDD+. Despite such challenges and doubts about REDD+, international efforts and financial support for REDD+ continue (Parlina 2015, Johannsdottir and McInerney 2016). Many different studies have looked at how REDD+ is being implemented on the ground (Burgess et al. 2010, Peskett et al. 2011a, Bolin and Tassa 2012, Naughton-Treves and Day 2012, Sills et al. 2014, Sunderlin et al. 2014a) in an attempt to pinpoint areas for improvement and pathways forward.

There is also a good deal of literature documenting some of the lessons that have been learned thus far, including how contextual factors might lead to, or prevent, effective outcomes. Effective implementation of REDD+ is contextual to different countries in which it is being implemented (Angelsen and Rudel 2013). For example, increased tenure security for forest communities can, but does not always, lead to effective REDD+ outcomes in Indonesia (Resosudarmo et al. 2014). Across countries, challenges toward effective outcomes are also found in conflicting stakeholder perceptions, complexities surrounding equity, and tenuous interest in REDD+ (Pasgaard et al. 2016). Nonetheless, the extensive body of literature on REDD+ in Indonesia (Santosa et al. 2013, Agung et al. 2014, Dixon and Challies 2015) and elsewhere (e.g., Naughton-Treves and Day 2012, Sills et al. 2014, Sunderlin et al. 2014a) indicate there is still more to learn as REDD+ projects continue to develop in many places.

Questions from the literature reflect key debates and concerns surrounding REDD+, specifically: how REDD+ will translate across scales from international and national discourses to local realities (Peskett et al. 2011b, Danielsen et al. 2013, Di Gregorio et al. 2013, Schroeder and McDermott 2014); whether REDD+ will be able to deliver on its promised benefits (Gardner et al. 2012, Murray et al. 2014, Lund et al. 2017) and if not, why not (Fletcher et al. 2016, Angelsen et al. 2017); and how REDD+ will actualize, both now and in the future (Turnhout et al. 2017). Our research attempts to address some of those questions by describing how three projects have been implemented locally in Indonesia, what promises may or may not be being met, and what challenges these projects are facing as a result of the political, financial, and stakeholder dynamics existing across scales and at the local level. Field research on the development of REDD+ projects has the potential to clarify existing challenges and inform future activities. Thus, we aim to contribute to the REDD+ literature by identifying and describing the criteria that can be used to assess REDD + projects in Indonesia as well as identifying challenges that arise in efforts toward effectively achieving project goals. The insights on REDD+ provided by this research are of interest specifically to the context of Indonesia, a country with the third largest tropical forest in the world, one of the highest 
global deforestation rates (Hansen et al. 2013), and a complicated forest management approach (Galudra et al. 2011, Indrarto et al. 2012), as well as to REDD+ efforts globally.

The criteria identified were chosen through review of the relevant literature and policy as well as through the results of fieldwork in Indonesia with REDD+ stakeholders. Challenges associated with these criteria will be assessed using examples from our research on three case studies of existing REDD+ demonstration projects in Indonesia. Despite challenges for REDD+ implementation, Indonesia's government has expressed enthusiasm for and engaged in REDD+ since 2008. Since that time over 40 REDD+ projects have been identified on the ground. In Indonesia, there is no single template for how a REDD+ project can or should be organized. The REDD+ National Strategy (IRTF 2012) provides an outline that offers many different ways for a REDD+ project to be designed and therefore there is a great deal of variation among projects, i.e., who is running them, who is funding them, and how they operate. Despite the diversity among projects, there are some essential common criteria that we argue are essential for achieving effective REDD+ outcomes. By assessing these common criteria at different project sites, there is a potential for identifying some of the major challenges to implementation and opportunities for the future. Using three case studies from different provinces in Indonesia, we are able to illustrate how challenges to REDD+ effectiveness can play out across a diverse landscape of locations and contexts.

\section{METHODS AND CASE STUDY SITES}

Data collection was undertaken from 2012 to 2014 in the form of participant observation, interviews, and a review of relevant forest policy. The ethnographic research was supplemented by a range of other sources including newspaper and other media reports, research publications, gray literature, and policy documents to understand the context of REDD+ stakeholder experiences and potential disconnects between the literature and what was happening on the ground. From our observations, reliable information concerning the realities of REDD+ and forestry in Indonesia can be difficult to obtain, and differences between public pronouncements, official documents, and local reality is often stark. Thus, triangulating the data in this way, i.e., spanning the full spectrum of forest policy from international to local scales and combining multiple sources with the results of our field work, provided insight into how international and national initiatives manifest themselves on the ground, increased the validity of the data (Decrop 1999), and helped to bridge the gap between literature, policy, and implementation.

This fieldwork took place at international, national, and local scales. Much of the data used were taken at the local level at project sites, but interviews with stakeholders involved in other projects were also included. Although most interviews took place in Indonesia, there were also some interviews conducted in Washington, D.C., where many organizations involved in REDD+ have headquarters. Data collection included participant observation and qualitative methods including interviews. In most cases, interviews were recorded with permission of respondents, or if an interview was not recorded, notes were taken during the interview. Data were analyzed using grounded theory and inductive methods, and interview transcripts and meeting notes were coded for major themes.
Participant observation involves site visits, or spending time at fieldwork sites and with informants to collect data through the observation of activity and phenomena related to the topic of research (Bernard 2006). Participant observation included time spent at each project site with project organizers and forest communities, as well as attendance at relevant meetings at local sites and in national level policy contexts. In addition to general site visits, participant observation was carried out at meetings between villagers and project organizers, among project organizers, and among villagers. Nine meetings were attended that were specifically related to one of the case study sites, and nine other meetings that were relevant to more general REDD+ issues were also attended. At these meetings extensive notes were taken, and they were sometimes recorded and transcribed. Notes and transcriptions from meetings were used in the development of themes for coding, but not included in the coding process itself.

All interviewees were stakeholders of REDD+. Stakeholders are defined as someone who is currently, or has previously been, somehow involved directly in the REDD+ program by working on a project, collaborating on a project, or living in or adjacent to a project, as in the case of forest communities. Initial interviewees were selected on the basis of the extent of their involvement in REDD+ activities, and from there a chain referral and preferential sampling method was used (Bernard 2006). Interviews were conducted with 71 stakeholders from a variety of stakeholder groups: donors, project managers, employees and heads of nongovernmental organizations (NGOs), government officials, policymakers, members of civil society organizations, academic researchers, and local forest communities. Of the 71 interviewees, 30 stakeholders were directly involved with 1 of the case study sites, and 41 were general stakeholders involved in REDD+ at the district, provincial, national, or international scale of operation. Most interviews were conducted in English, but when necessary interviews were conducted in Bahasa Indonesia, or with the assistance of a local translator.

Informal semistructured interviews are conducted with a standardized list of questions that are then followed up with further probing and exploration of important topics as they are introduced by the informant's response (Bernard 2006). Informal semistructured interviews are beneficial for research, such as this, that includes respondents that demonstrate a wide array of experiences and perspectives (e.g., government officials, project organizers, forest communities, etc.). These types of interviews provide structure throughout the interview process while still allowing for variation when an informant provides key information, which can then be explored in more depth. The interviews consisted of approximately five to seven standardized questions developed based on relevant literature and preliminary scoping fieldwork. These questions were usually followed by additional questioning to further explore any key topics brought up during the interview. Interviews began with broad questions aimed at getting a general understanding of each respondent's experiences with REDD+, followed by a further probing of challenges, effectiveness, or perceptions of the program.

When possible interviews were recorded with the permission of the respondent, and in the case of a few exceptions, meticulous notes were taken. Interviews were transcribed and entered into a TAMS analyzer database to apply a grounded theory approach 
to analyzing the data (Charmaz and Belgrave 2002, Charmaz 2006). Grounded theory and inductive coding methods use a bottom up, rather than top down, approach and involve using data collected for the study to form a framework for interpreting and understanding the data (Charmaz 2006). Following an inductive coding method (Corbin and Strauss 2007), interview and meeting transcripts were reviewed at various stages of data collection to develop a list of coding categories based on recurring themes and issues mentioned by respondents. All interview transcripts were coded using these categories. The themes that emerged from the interviews were compared with literature and policy review to identify criteria that can provide insight into achieving effectiveness in REDD+. These themes and the results of coding were also used to ascertain the major challenges for the projects in our case study with regard to these criteria.

Initially, interview transcripts and notes from meetings were coded according to broader categories such as: REDD+ criteria necessary for project implementation and effectiveness; challenges; failures; successes (effectiveness); results; and attitudes/perceptions. The REDD+ criteria necessary for project implementation and effectiveness category refers to topics related to essential components of REDD+ projects including: funding, community engagement, monitoring, governing capacity, biodiversity preservation, and carbon sequestration. The challenges category included: corruption; cultural barriers; lack of pathways for implementation; communication issues; overlapping authority; confusing regulations or policies; stakeholder conflicts; disconnects (between levels of governance, stakeholders, or perceptions and reality); logistical/procedural challenges; and lack of buy-in (by other stakeholders). Failures and successes/effectiveness were coded when anecdotal instances of either were shared. Attitudes/perceptions included: stakeholder fatigue; buy-in (either positively or lack of buy-in); hopelessness; lack of confidence in REDD+; confusion; doubt; and hope. Less frequently mentioned topics were not included.

\section{Study limitations}

Although our research has generally achieved its aims, there were some unavoidable limitations. For one, visiting REDD+ sites and collecting in-depth data was very time intensive and because of time limitations, we were only able to visit three REDD+ projects. Indonesia is a country with vast cultural and geographic diversity, and in different regions in which REDD+ is implemented; such diversity results in variation in project design, implementation, and challenges. Because of this diversity, visiting more REDD+ projects would have added further insight and should be considered an opportunity for future research. To help offset this, there were interviews conducted with stakeholders involved in REDD+ projects other than the three included, and the data from their interviews have been included in the results. In general, qualitative data collection always faces the possibility of being impacted by selection bias. Furthermore, because two of the projects in this case study have not undergone independent monitoring, it is not possible to quantitatively assess how forest cover and biodiversity levels may have changed, or been maintained, for those projects' duration. Without quantitative information from monitoring of forest cover and biodiversity levels, it is difficult to assess exactly how these projects have reduced forest cover loss or improved biodiversity levels. In the future, as monitoring becomes more and more available in countries implementing REDD+, there will be more opportunities to explore these topics.

\section{Case study sites}

After initial consultations with REDD+ stakeholders, researchers, and policymakers, the three REDD+ projects were chosen as suitable case study sites. These 3 were chosen from the 40 projects in Indonesia because they demonstrate many characteristics representative of other projects throughout Indonesia. These characteristics include the structure of the projects, the goals, the funding, and their status as REDD+ activities. In terms of project structure, ecosystem restoration concessions (ERCs), community based conservation projects, and projects built on pre-existing conservation initiatives are the predominant form that REDD+ projects in Indonesia take. There can also be projects initiated at the district level, an approach that has been encouraged by the World Bank's Carbon Fund. Two of the projects, Hutan Harapan and Rimba Raya, are ERCs and were designed with the intention of taking advantage of new funding and policy opportunities offered by REDD+. The other project, Kapuas Hulu, is a community based forest conservation initiative that seeks to take advantage of the opportunities for recognition by local and national governments that have been created by REDD+, but not necessarily the funding. Each case study site is funded in a different way, illustrating how different projects obtain, or fail to obtain, funding. For example, Rimba Raya has obtained funding through the Carbon Market, and at the time of this research was the only REDD+ project in Indonesia to have done so. Harapan has a variety of donors, but at the time of this research was still struggling to obtain long-term sustainable funding, something common among projects in Indonesia. Kapuas Hulu is funded through the organizing agency that initiated the project. Each of these projects was created with some goals that overlap and some goals that differ, demonstrating how projects in Indonesia come to be structured somewhat differently. For example, although all REDD+ projects share the goal of sequestering carbon, others also have biodiversity protection or community rights as top priorities. Each of the case study sites is well known in the REDD+ context and has also been identified, at some point, as being an official REDD+ project in Indonesia. Although this is one characteristic that was important for our sample of case studies, the status as an official REDD+ project actually means little more than recognition as such by various stakeholders.

The complexity of Indonesia's governance system provides a complicated background for forest conservation activities (Galudra et al. 2011, Enrici and Hubacek 2016), and REDD+ has developed there in an equally complex way. REDD+ projects can be, and have been, started by stakeholders at a variety of scales, i.e., international (as in the case with the UN REDD+ pilot program), national, district, and project level. Some of these were initiated as a way to gain support for already planned, or underway, conservation activities. Other REDD+ projects were developed to take advantage of potential funding and support opportunities that came about from the introduction of REDD+. As a result, there are some projects and efforts in Indonesia identifying with REDD+, which may vary in both design and goals from the initial idea of REDD+. 
There are multiple ways that a REDD+ project can form, based on existing conservation projects, within national parks, based on community forest areas, or as an ERC. Licenses for ERCs are issued specifically for production forests, which are designated for industrial use by the Ministry of Forestry, and experience extremely high rates of deforestation (Margono et al. 2012, 2014). Thus these projects have the potential to play a particularly important role in reducing deforestation in Indonesia. REDD+ projects are needed in the case of established conservation projects, which may need more funding, or in National Parks, which in Indonesia are still quite vulnerable to degradation (Gaveau et al. 2007, 2013, Yuliani et al. 2010).

The first case study site, Harapan Rainforest, is located in Jambi, Sumatra and was initiated by three conservation organizations: Burung Indonesia, BirdLife International, and the Royal Society for the Protection of Birds. These three organizations started a private ecosystem restoration company, PT Restorasi Ekosistem Indonesia (PT REKI), to obtain an ERC license because ERCs can only be obtained by a private entity in Indonesia. Harapan was the first ERC license to be issued by the Ministry of Forestry in 2008. Harapan was initiated by these conservation organizations hoping to use REDD+ as a way to achieve conservation goals broadly oriented toward protecting various species of birds and their habitats. Helping to restore the ecosystem, which has been severely degraded over the past 50 years (Buergin 2016), is the basis for Harapan's ERC license. Afforestation efforts as well as the prevention of further use of the area for logging or palm oil are planned to achieve this. Sumatra has faced significant rates of deforestation over the past 50 years, with a decrease in natural forest cover from 58\% in 1985 to $29 \%$ in 2008 (Uryu et al. 2010). Timber extraction in Sumatra has been a cause of degradation for decades (Kissinger et al. 2012), and oil palm dominates much of the landscape throughout the island (Koh et al. 2011). Jambi was chosen as a focus province for REDD+ implementation by the REDD+ Agency and the United Nations Office for REDD+ Coordination in Indonesia (UNORCID). Both UNORCID and the REDD+ Agency had planned to open offices in the provincial capital of Jambi City, however, since the time of our fieldwork the REDD+ Agency has been slated to be merged with the new Ministry of Forestry and Environment (Jong 2015).

Although Harapan was initially designated and recognized by relevant agencies as a REDD+ project, it has since chosen to disassociate with the REDD+ program. This disassociation came as a result of the negative attention and controversy (Lang 2013) that PT REKI felt the project received as a result of their association with REDD+, and is evidenced by their lack of mention of REDD+ on their website (http://hutanharapan.id/ harapan). So although the Harapan project still identifies as an ecosystem restoration project, it does not officially self-identify as a REDD+ project. Terminology regarding REDD+ has been removed from its website and when speaking with project organizers and employees, they assert that Harapan is no longer a REDD+ project. This is something that has been reported with other REDD+ projects as well (Sunderlin et al. 2014a). Unlike many of Sumatra's lowland forests that have been converted wholesale into palm oil, Harapan was previously a logging concession and was logged legally until 2007 (Beckert et al. 2014). Having been a site for timber extraction in the 1970s, the 98,000 ha area of tropical forest has, like much of Sumatra, faced degradation over the past 50 years. However, Harapan is still widely considered to be a hotspot for biodiversity (Rands et al. 2010, Marthy et al. 2016), and the current project is directed toward restoration of the area's ecosystem including afforestation goals as well as protecting and promoting biodiversity. The indigenous forest communities in the area, the Batin Sembilan, were at some point nomadic but in recent years shrinking territory from increasing palm oil plantations and government resettlement programs have encouraged less movement among the communities (Colchester et al. 2011) and many have had to settle in the Harapan project site.

The second project, Kapuas Hulu, is located in Kalimantan Barat, or West Kalimantan. The Kapuas Hulu project was initiated by an aid organization with the intention of using the logistical advantages created by REDD+, such as recognition by the local government, to undertake a community-based conservation project. This REDD+ project is facilitated by the Forest and Climate Change Programme (FORCLIME), as part of the Deutsche Gesellschaft für Internationale Zusammenarbeit (GIZ). The project is not an ERC, but is instead based on a cluster of Dayak villages and their community forests, which have the potential to provide an ecological corridor between two National Parks: Danau Sentarum and Betung Kerihun. The exact number of hectares included in the project have not been disclosed publicly.

The project is located in the Indonesian area of Borneo, Kalimantan, the second most heavily forested of Indonesia's seven major islands, and the province of West Kalimantan contains the largest intact forest on the island (Margono et al. 2014). The extent of West Kalimantan is approximately 14 million ha and has 8.8 million hectares of government designated forest area, 5 million ha of which are designated for timber production (Yasmi et al. 2006). Kalimantan has experienced high levels of deforestation (Gaveau et al. 2016) as a result of industrial activity such as the rapid expansion of palm oil plantations (Carlson et al. 2013). Kapuas Hulu, also the name of the district in which the project is located, is a heavily forested district in the province of Kalimantan Barat; it shares a border with Malaysia and is located over 500 kilometers from the capital city of Pontianak.

The third project is located in another of Kalimantan's provinces, Central Kalimantan, which experienced the second highest rate of deforestation from 2000 to 2008 (Broich et al. 2011). Rimba Raya, like Harapan, is also an ERC, run by a private entity, Infinite Earth, which was founded with the express purpose of creating a business based on conservation of the forest. Rimba Raya, the company's first project, was initiated to take advantage of business opportunities arising from REDD+. The project area of Rimba Raya, covers $\sim 64,000$ hectares and borders Tanjung Puting National Park, providing a buffer zone to the park from nearby palm oil plantations. Tanjung Puting and Rimba Raya are both habitats for the endangered Borneo Orangutan. Central Kalimantan was initially designated as the first pilot province for REDD+, though several large REDD+ projects there, such as Rimba Raya, have struggled to obtain ERC licenses (Walsh et al. 2012). Rimba Raya began petitioning for its ERC permit in 2010 , spent several years navigating the bureaucratic process, and was finally granted one in 2013. The majority of the villages involved in the Rimba Raya project are local Dayak ethnic groups. 
Two of the case study sites, Harapan and Rimba Raya are ERCs and they are being run as more traditional payment for ecosystem services (PES) projects (Pagiola and Platais 2002). The other, Kapuas Hulu, does not have a unified forest concession and is more focused on forest conservation through community empowerment. All three of the projects have demonstrated some effectiveness in achieving goals and have experienced some challenges along the way, although the ways in which they have been most effective and faced the biggest challenges varies with each project. In the following sections the major criteria of REDD+ projects that are essential for achieving and demonstrating effectiveness in carbon sequestration and biodivers

\section{CRITERIA FOR EFFECTIVENESS OF REDD+ PROJECTS IN INDONESIA}

These criteria were chosen by using initial evaluation of participant observation and major themes derived from interview transcripts, combined with literature and policy review. Even though REDD+ demonstration activities all more or less aim to achieve some level of carbon sequestration and forest conservation, they all also have varying degrees of emphasis on community engagement, carbon sequestration, and biodiversity preservation. Regardless of variation among projects, there are some common criteria identified as necessary for effective REDD+ outcomes. (Table 1)

Table 1. Criteria for achieving effective outcomes for REDD+ projects in Indonesia.

\begin{tabular}{|c|c|c|c|c|c|}
\hline \multirow[b]{2}{*}{$\begin{array}{l}\text { Project } \\
\text { Name }\end{array}$} & \multicolumn{5}{|c|}{ Criteria } \\
\hline & Finance & $\begin{array}{l}\text { Community } \\
\text { Involvement }\end{array}$ & Monitoring & $\begin{array}{l}\text { Boundary } \\
\text { Enforcement }\end{array}$ & $\begin{array}{c}\text { Carbon \& } \\
\text { Biodiversity }\end{array}$ \\
\hline $\begin{array}{l}\text { Harapan } \\
\text { Rimba } \\
\text { Raya }\end{array}$ & $\begin{array}{l}- \\
+\end{array}$ & + & $\begin{array}{l}- \\
+\end{array}$ & - & $\begin{array}{l}? \\
+\end{array}$ \\
\hline $\begin{array}{l}\text { Kapuas } \\
\text { Hulu }\end{array}$ & $+1-$ & + & - & $+/-$ & $?$ \\
\hline $\begin{array}{l}\text { Key: } \\
+: \text { has ac } \\
+/- \text { : some } \\
-: \text { has yet } \\
\text { ?: unverif }\end{array}$ & $\begin{array}{l}\text { yed some e } \\
\text { ectiveness } \\
\text { achieve eff } \\
\text { uncertain }\end{array}$ & $\begin{array}{l}\text { ectivenes } \\
\text { ut still facing } \\
\text { tiveness } \\
\text { utcomes }\end{array}$ & g some challe & nges & \\
\hline
\end{tabular}

Each of these criteria were mentioned frequently in our interviews and fit into the coding theme "REDD+ criteria necessary for project implementation and effectiveness," and they were also all prevalent in the relevant literature. Funding was chosen as a criterion because lack of available funding was frequently reported by our respondents and is an obvious necessity for running an effective conservation project. Although the importance of finances and funding of REDD+ have been discussed at length in the REDD+ literature (Butler et al. 2009, Creed and Nakhooda 2011, Streck 2012, Norman and Nakhooda 2015), it is still an important criterion to acknowledge and discuss. This is at least in part because based on our research, stakeholder reports of insufficient funding at the project level in Indonesia contrast starkly with some stakeholder perceptions at the national level. Community engagement was chosen as another essential criterion to consider for assessing effectiveness of REDD+ projects because it has been widely discussed in REDD+ literature
(Agrawal and Angelsen 2009, Jagger et al. 2012, Lawlor et al. 2013), and frequently mentioned by stakeholders from our research. Community engagement is widely discussed as important for REDD+ effectiveness (Agrawal and Angelsen 2009, Hayes and Persha 2010, Sunderlin et al. 2014b) and presents challenges in Indonesia (Resosudarmo et al. 2014) and elsewhere (Phelps et al. 2010). Governing capacity was chosen because of its presence as an important topic in the literature and the prevalence with which it came up in our research. For the purposes of this discussion, governing capacity will specifically refer to enforcement of project boundaries and monitoring. Encroachment when there is a lack of ability to enforce boundaries has been an ongoing issue in Indonesian forest management (Curran et al. 2004, Gaveau et al. 2007, Murdiyarso et al. 2011, Mattangkilang 2013). Although establishing protected forest areas can lead to reductions in deforestation and degradation, encroachment still occurs in many areas (Gaveau et al. 2013, 2016). This is a problem that also affects REDD+ projects, as reported by stakeholders from this research and so is an important criterion to include. The other aspect of governing capacity, monitoring, is also recognized as important for assessing the effectiveness of REDD+ projects (Pratihast et al. 2013, de Sassi et al. 2015) though working out the details of how exactly monitoring will be carried out has been a matter of debate among many interested in REDD+ (Fry 2011, De Sy et al. 2012, Danielsen et al. 2013, Beaudoin et al. 2016). Carbon sequestration, through a reduction in deforestation and forest degradation, was the initial goal for REDD+ and is a crucial outcome for REDD+ projects, necessary for demonstrating overall project effectiveness.

\section{Funding}

Although evaluating a project based on its involvement in the carbon market may be too strict a measure of effectiveness, at the very least a project must have access to, or a plan for finding sustained funding for the present and future. Many projects were initiated in the hope of securing funding from either the carbon markets or from a REDD+ finance mechanism, but in many cases funding has remained elusive. One particularly striking example can be found with the United Nations' REDD+ Pilot Project in Indonesia, which lists a lack of funding as one of the two main reasons for its eventual demise (UN REDD Programme 2013). Although all of the projects included in this case study had secured some level of funding, the process of obtaining long-term and sufficient funding was one of the most frequently mentioned challenges by the stakeholders included in our fieldwork (Dixon and Challies 2015, Well and Carrapatoso 2016).

Despite the importance of sufficient long-term funding for REDD+ projects, it is not always sufficiently addressed in the conservation literature (Phelps et al. 2011) and policy discussions (Vijge et al. 2016). As a result of varying access to carbon markets and differing initial goals, various projects in Indonesia have different amounts and sources of funding. Although many conservation initiatives globally lack sufficient funding, the issue is important to discuss for REDD+ in Indonesia because of the stark contrast between some initial perceptions of large funding opportunities among some stakeholders and the absence of funding on the ground.

One international-level stakeholder representing a foreign donor government said: 
...certainly, I think funding is not going to be the constraint, I think the constraint is going to be to identify good, strategic, important projects. Respondent ID 10373.

This perspective differs greatly from perspectives of stakeholders on the ground. Project-level stakeholders repeatedly noted lack of funds. As one such stakeholder said:

...it's hard to find funding. Respondent ID 10389.

Another said:

...it's totally unclear what the finance is going to be. Respondent ID 10378.

As one stakeholder put it:

[REDD+] is not working here because people expect lots of money and when it runs out they leave. Respondent ID 10423

Another said:

There's no money coming through to anyone. It was kind of the general complaint...like, great, we have all these meetings, but we're trying to make a living out here. Respondent ID 10386.

The perception of large funding opportunities likely exists because of large sums promised by foreign governments (Barrett and Goldstein 2016). The mismatch between the initial perception of funding opportunities and the availability of them may have led some REDD+ projects to develop before the financial component was secured.

Funding is an essential, seemingly obvious, criteria for a REDD+ project, yet many respondents from our research report that the lack of sufficient funding from a REDD+ mechanism or the carbon market has left many projects with the task of searching for funding from other areas. We define sufficient funding as having, or a reasonable trajectory for obtaining, enough funds to keep the project operational and allow it to continue into the future. Although the exact amount of time that will define "future" may differ from project to project, many projects in Indonesia must search for long-term funding because of the nature of ERCs in Indonesia. These have terms for at least 60 years, and sometimes for 99 years or longer. The ERC permit obtained by both Rimba Raya and Harapan Rainforest is a license for operating a REDD+ type program on production forest (forest marked for private use, logging, palm oil, mining, etc.). This kind of license gives holders rights to the land for an extended period of time and includes an agreement for a licensing fee paid to the central Indonesian government. As Walsh et al. (2012:36) put it: "Ecosystem restoration is a long-term process that will require sustained funding. Applications for an ER [license] must include a business plan that outlines how revenue will be generated over the life of the concession [license], which may exceed 100 years." The amount required for these payments is substantial and adds to the costs already associated with running a REDD+ project. Licensing fees, for example, have been reported to range from US\$0.6 million (Indriatmoko et al. 2014) to US\$1.4 million (Walsh et al. 2012).

REDD+ is fundamentally a PES scheme in that the initial idea behind REDD was to provide payment for carbon sequestration.
Traditional ideas for payment for ecosystem services schemes include buyers and sellers and an attempt to internalize natural resources that have been externalized from the economy, yet many REDD+ demonstration activities have deviated from this structure (Peskett et al. 2011a). In the case of Indonesia, REDD+ buyers are not present for many of the sellers, and so many demonstration activities face challenges in securing sufficient funding and often turn to alternative funding options outside of carbon payments. Although carbon markets have begun to gain momentum in recent years (Hamrick and Goldstein 2015), commodification of carbon has still proven problematic because of failures to set global carbon prices (Kalkuhl et al. 2015) and carbon-offset projects do not always have the potential for financial solvency (van Kooten et al. 2015). Moreover, because of concerns about potential for actually reducing emissions, many forest conservation activities including REDD+ are excluded from some carbon market mechanisms including the compliance market (Butler et al. 2009, Carbon Market Watch 2013). At Conference of Parties 2015 (COP21), it was acknowledged that carbon markets are insufficiently developed to support climate change mitigation efforts (Johannsdottir and McInerney 2016), resulting in carbon markets that cannot provide sufficient and accessible funding for many stakeholders attempting to implement REDD+ projects. As a result, many REDD+ stakeholders, working on projects not already funded by aid agencies or NGOs, find selling carbon credits provides insufficient funds.

One project organizer stated:

One of the toughest things is carbon credits, the market is still soft. We could have 2 million a year in carbon credits, [but we] can't sell them all. Respondent ID 10384.

And one national-level foreign respondent said:

Over the last year, it's really gotten questionable. I mean I've started asking some of the [big NGOs] what their policy is if nobody is buying these credits. Well, we haven't really figured that out yet... In a way, it's a real tragedy because there's a lot of people out there [who've] invested a lot of time and effort and money into producing REDD credits, and now the worry is nobody will buy [them]. Of course, there's still a voluntary market but there's not the huge increase in demand everybody anticipated. Respondent ID 10366.

Furthermore, carbon sequestration as a payment for ecosystem service has proven difficult to implement, in part because of the complexities associated with carbon finance mechanisms. The economics of carbon sequestration may not provide sufficient funding for competition with other potential forest-land uses (Butler et al. 2009, van Kooten and Johnston 2016).

This is something that stakeholders are well aware of, as one stakeholder put it:

The other issue is REDD money is not unlimited. It's going to be a drop in the bucket compared to what palm oil revenue, for example, brings in or pulp and paper. So how do you address real drivers of deforestation? Like, how do you really do that? And how can you use REDD to really do that? I don't know. Respondent ID 10379. 
Another aspect of this complexity is that a growing forest actively sequesters more carbon than a mature one (van Kooten and Johnston 2016). However, biodiversity preservation is also an important aspect of REDD+ and so baselines must be established to demonstrate the value of standing forests, though in many cases globally they have not yet been established (Virah-Sawmy et al. 2015). Because of this, looking exclusively at how much carbon is sequestered for financial compensation could potentially encourage those seeking money from REDD+ initiatives to deforest or degrade an area to obtain more funding. Thus, many projects must not just actively demonstrate the increase of carbon stock in an area but need to prevent existing carbon stocks from being released into the atmosphere through deforestation or degradation of that land. Indeed, many projects are preventing old growth forest from being degraded or cleared by other potential land uses, such as palm oil or mining. In these cases, they are demonstrating additionality, or that the benefits would not have occurred under a business as usual scenario (Melo et al. 2014).

From our case study, Rimba Raya fits under this category of demonstrating additionality, and to some extent so might Kapuas Hulu and Harapan. However, Harapan's forest cover was degraded before the concession became an ERC so there is some potential for further sequestration as the forest is restored. At the time of this research, neither Kapuas Hulu nor Harapan had done an independent audit to establish baselines, as Rimba Raya has done. A baseline for emissions reduction and forest cover must be established for projects to provide a starting point for assessing total carbon stock in an area and to facilitate the monitoring of a project's progress in improving or maintaining carbon stock. This information is essential for certain types of funding, because it can then be used to calculate the total amount of carbon credits that a REDD+ project might have to sell on the carbon market. The lack of a robust carbon market, however, means that projects often do not have opportunities to find funding through this avenue, regardless of established baselines and carbon stock.

There are other entities besides the carbon market that can potentially provide funding for REDD+ projects, although in some cases these too have proven difficult to access. The Carbon Fund is active in Indonesia and has been engaged in developing about a dozen projects around the country but is not currently available for funding to other projects. Although Norway has promised funds for countries involved in REDD+, 1 billion USD in the case of Indonesia, the disbursement of those funds is predicated on demonstrable results, which to date have not yet been actualized (A. M. Enrici, personal communication).

In terms of available funding, it is unclear exactly how much is available for REDD+ projects. At the time of writing no official statements had been issued by Indonesia's government, whereas Norway's government reports approximately $8 \%$ of the 1 billion USD promised to Indonesia have either been released or committed (Norwegian Embassy in Jakarta 2016). Norway's government has also stated that at least $80 \%$ of their initially promised 1 bllion USD is being reserved for performance-based results, none of which has yet been dispersed (Royal Norwegian Embassy in Jakarta 2016). Thus, despite widely reported, substantial funding for REDD+, many projects are lacking basic funds to support on-the-ground efforts. Many projects were initiated with assumptions that these funds or carbon markets would be easily accessible for project funding, yet that has not been the case for many REDD+ stakeholders. It may even be possible that perceived projections of available funding has actually undermined REDD+ effectiveness by overselling ideas about available funding and encouraging some projects to be initiated without a solid plan for obtaining financing. This is the case of the UN Pilot Project in Sulawesi, which reported lack of funding as one reason the project failed after several years of preparatory activities (http://www.un-redd.org/).

As one stakeholder put it:

We must meet all government requirements, but it's very expensive. We can't make any money to pay for other things, like getting rid of encroachers. Respondent ID 10420.

So despite great hope from promised funds, funding has remained out of reach for many REDD+ stakeholders and projects.

At the time of this research, the Rimba Raya project was the only REDD+ project in Indonesia having secured funding from the carbon market. Rimba Raya stated that half of their 10 million tons of certified emissions reductions had been sold, but according to project organizers that only ensures funding for the near-term future. The rest of the credits still needed to be sold to sustain the project over the long-term of the ERC license. While acknowledging the difficulties that a lack of general funding sources have created, project organizers attribute their success to approaching REDD+ as a business. Doing so has meant persevering even when faced with seemingly insurmountable challenges, spending as little as possible on unnecessary costs, and prioritizing what is important and necessary.

As one project organizer put it:

People that are typically involved in REDD have very little business experience. So at this stage of the game, the only people who have succeeded are primarily people who have business experience. If you're not very results based or very focused on what's important and able to prioritize, you won't see what's important. A business person has to do that because of what [running] a business requires... There's no room for error. But I see people here, they get their money from the clouds and they spend it because ita's not theirs. And we spend our own money. People that invested in us and trusted in us, so we couldn't lose that money. Respondent ID 10382.

In terms of finance, Rimba Raya has demonstrated as much effectiveness as any REDD+ project in Indonesia in obtaining their own funding.

Some projects, such as the Kapuas Hulu project, have a reliable and somewhat long-term funding source outside of the carbon markets. The Kapuas Hulu project in KalBar was, at the time of this research, run by GIZ's FORCLIME project, which had secured a 26 million USD grant through KfW Bankengruppe, a German government-owned development bank. This offers an example of an alternative pathway for REDD+ projects to have financial viability, i.e., through donor organizations that are willing to offer substantial funding for a project. In the case of a $\mathrm{REDD}+$ project that is not being organized as an ERC, the need for sustained long-term funding might not be as urgent as for 
those that are ERCs with all of the associated fees. And although this kind of direct donor funding is not always available for some projects, it is for others. In the case of the Kapuas Hulu project, the funding was part of GIZ's budget and therefore obtained before the project was undertaken. There are some other projects that are set to receive funding from the World Bank's Carbon Fund, in a similar manner to the Kapuas Hulu project.

The case of Harapan most clearly illustrates the difficulties in securing sufficient long-term funding, an issue both recognized in the literature (Phelps et al. 2011, Streck 2012, Busch 2013, Dixon and Challies 2015, Vijge et al. 2016) and widely reported by respondents from our research outside of these three case studies. In an experience similar to what has been reported in the literature (UN-REDD Programme 2013) and by many other of our interviewees, project organizers initially thought that funding could be secured through the carbon market, the Norway money, or the U.N. REDD+ program itself, but later when financing did not materialize, funding alternatives had to be sought.

One respondent, associated with another project outside of these case studies put it like this:

$$
\begin{aligned}
& \text { We're trying for REDD, but we feel left out...it's hard to } \\
& \text { find funding and sometimes we ask ourselves, what's in } \\
& \text { it for those of us running the project? Respondent ID } 10403 .
\end{aligned}
$$

At the time of our research, Harapan reported their only avenues for securing funding outside of the carbon market were from various donors, which have included: Danish International Development Agency (DANIDA), the German International Climate Initiative (ICI), Singapore Airlines, and through nontimber forest products (NTFPs) (such as gaharu, handicrafts, honey, etc.). Neither these donors nor the nontimber forest products are providing a long-term option for sufficient funding to sustain the project. This has left the project with the challenging task of securing alternate funding while also trying to successfully implement other project objectives. Alternate sources of revenue often cannot provide sufficient funding for a project to remain economically viable in the long term (Butler et al. 2009), certainly cannot compete with other potential land uses while supporting the costs of project maintenance, and last over the 100-year term of an Indonesian ERC.

\section{Community engagement}

Although fair and equitable community engagement has been acknowledged as a crucial criteria for REDD+ and other climate change mitigation programs (UNFCCC 2010), in many places community engagement in REDD+ has not been sufficient (Danielsen et al. 2013, Lawlor et al. 2013, Bayrak and Marafa 2016). Early on in REDD+, the importance of involving forest communities had been acknowledged and incorporated into most REDD+ frameworks (UN REDD Programme 2011, IRTF 2012, Howell 2015). There is increasing evidence to support the positive effect of involving communities in effective forest management endeavors (Molnar et al. 2004, Stevens et al. 2014). Although there is still some debate that assuring community rights will necessarily result in effective long-term forest management (Resosudarmo et al. 2014), doing so at least has the potential to improve chances of long-term project effectiveness (Agrawal and Angelsen 2009, Stevens et al. 2014). Furthermore, it is almost universally agreed that projects must involve communities in a fair and equitable manner.
Indonesia has a vast population of forest communities; estimates range between 80 and 95 million and are defined by the Forest Peoples Programme as "Indigenous peoples who depend primarily on natural...forests for their livelihoods...; rural people who live in or at the margin of natural forests or woodlands, who rely on the forest as a safety net or for supplemental income; smallholder farmers who grow farm trees or manage remnant forests for subsistence and income; artisans or employees in formal or informal forest-based enterprises" (Chao 2012:8). To ensure the fair treatment in the engagement of such communities in REDD+, a system was adapted called Free Prior and Informed Consent (FPIC). The idea behind FPIC is to ensure that communities are engaged and truly understand what they are agreeing to with that engagement.

Although reasoning behind the provision of FPIC to communities is hard to disagree with, it has resulted in some communities being approached and informed about REDD+ long before projects could get up and running, and resulted in stakeholder fatigue. Stakeholder fatigue in forestry occurs when "key stakeholders begin to drop out of the selection process due to lack of perceived progress" (Hagan and Whitman 2006:208). Mistrust toward, and doubt about, REDD+ were themes commonly mentioned by community members and stakeholders in general, included in our fieldwork.

As one national level stakeholder put it:

You're going around bothering people all the time, asking them a million questions, getting data so that you can write a paper or report...I mean, the people don't understand, and...they are so fatigued...they're like "Please, go away." Respondent ID 10383.

This fatigue was reported to have resulted when the process had dragged on over a long time period (up to three years in the case of a some projects working to obtain an ERC) without seeing effective outcomes.

This is not something that is unknown to project organizers, as one REDD+ project organizer put it:

\section{I think a lot of it too is that the stakeholders don't believe in [REDD+]. So many have failed, so many have talked, then they don't believe in it anymore. That was sort of us the last few years during the delay. Up until the delay, everybody was supportive, all of our community. Everything was full blast. But then the delay [happened], and they start wondering. But I think in general, worldwide, there's a fatigue. There's a lot of fatigue. People have heard and heard and heard. Respondent ID 10419.}

Beyond initial involvement, the literature reports that community engagement and benefit distribution have proven complicated (Lawlor et al. 2013), something that reflects the multifaceted experience of the stakeholders included in this research. There are many questions that remain for stakeholders of REDD+, in Indonesia and elsewhere, about how to engage communities and how to distribute benefits. For example, should benefits come in the form of payments, or schools and access to medical care and how to ensure that benefits are not unevenly accumulated by certain members of the community. Although these questions have not yet been answered, many REDD+ project organizers 
have had to address them as they have moved forward with REDD+ activities.

As one stakeholder put it:

We haven't figured benefits [distribution] out, but whatever we do, it's got to be practical. It's got to work for these guys. They've got to see real tangible benefit or they're not going to support the program. Respondent ID 10371 .

The Rimba Raya concession is situated next to palm oil plantations, with communities located along the border, and as a result, these communities are engaged with both the palm oil company and Rimba Raya. Some of the communities receive fuel for generators or other benefits, and others are employed by the palm oil company. Although community members acknowledge palm oil's role in deforestation in the area, they report having mixed feelings about the palm oil company. Rimba Raya's plan for community benefits includes providing alternative employment opportunities, health care, clean drinking water, alternative fuel supplies, and other infrastructure (http://rimbaraya.com). Although not all of these benefits had been fully implemented at the time of data collection, an independent monitoring agency evaluates Rimba Raya's community engagement to ensure these objectives are being met. Communities are also still allowed access to the forests for certain things: harvesting of nontimber forest products and for fishing using sustainable methods. Some members of these communities demonstrate feelings of fatigue toward the project after hearing about REDD+ for years without seeing what they feel are real results. This is exemplified by the fact that some community members have engaged with the palm oil company, reflecting the challenge faced by Rimba Raya to get full community support and engagement. This may be due, at least in part, to the delay in Rimba Raya getting full approval for their ERC license. Rimba Raya provided FPIC to the communities upon the initial creation of the project as early as 2010 (Indriatmoko et al. 2014) but as it then took three years for them to get the project running and to secure the concession license, there was a delay in real implementation, resulting in stakeholder fatigue.

Community involvement is the basis for the project in Kapuas Hulu, and of the three case study sites, they have arguably demonstrated the most effectiveness in incorporating forest communities into their project. FORCLIME has undertaken a collaborative management approach and developed a strong working relationship with the Kapuas Hulu communities. Meetings are held regularly to give the communities information about, and choices in, project activities and direction. They also have employed community liaisons to work with FORCLIME staff and update the community at large about the project. Funding was given to each community involved in the project to supplement subsistence sources and income. Each community voted on what to do with the funding, choosing from a variety of projects suggested by Deutsche Gesellschaft für Internationale Zusammenarbeit (GIZ), followed by community implementation of projects revolving around nontimber forest products (coffee, agarwood, rubber, fish ponds, or vegetable gardens) and each community now has one or more of these underway. Communities became involved in projects from this initial stage, collaborating on both project design and implementation. The main challenge facing Kapuas Hulu and community involvement has to do with the Indonesian system of land tenure and establishing community ownership of the forest. This is characteristic of challenges for REDD+ projects and other aspects of forest management in Indonesia (Barr et al. 2006, Sunderlin et al. 2014b). More specifically in the case of Kapuas Hulu, there is currently a notyet-activated palm oil license overlapping with the community forest. Based on our interviews, it seems that although the palm oil company has approached community members about activating their license, the community remains mostly against the development of palm oil in the area. Although a few community members are enticed by the cash and jobs offered by the palm oil company, many other community members are suspicious. They have seen other areas converted to palm oil, and report that nearby communities, some of whom are relatives, are not pleased with the results, citing reports of a lack of fish and other forest products, combined with more frequent flooding and other issues.

As one community member put it:

We do not want palm oil here, we know if we had it here we would not have clean water anymore. Respondent ID 10429.

As a result, community support for protection of the forest remains strong. However, even though FORCLIME's REDD+ project demonstrates strong community engagement, the situation remains tenuous because of insecure forest tenure.

Community involvement has come with challenges for the Harapan project because the Batin Sembilan have been marginalized, and land conflicts have existed in the area long before the project was established (Colchester et al. 2011). Although some nomadic Batin Sembilan still reside within the concession, the nomadic tendencies of the Batin Sembilan have diminished with time, as a result of shrinking territory caused by the expansion of palm oil and government resettlement programs. Some of the Batin Sembilan now live in a permanent settlement that was developed with the assistance of the Harapan project, and according to project organizers, many community members have been drawn to the project site because of the diminished forest cover in the surrounding area. The Batin Sembilan still do not hold land rights to the area, though Harapan has established an agreement with the local communities living in and near the concession to allow the use of parcels of land and the collection of NTFPs. Communities have also been employed by the Harapan project to plant new trees, run the nursery, and guard the concession from encroachers. A small school and access to health care have been made available to all community members living in the Harapan concession. Although the relationship between Harapan and the Batin Sembilan is generally amicable as reported by our respondents, there have also been disputes over land rights when customary leaders have engaged in informal land trade agreements, resulting in conflicts (Beckert et al. 2014).

\section{Governing capacity: enforcement of project boundaries and} monitoring

In many countries in which REDD+ is being implemented, achieving and maintaining effective capacity for local forest management is a challenge (Minang et al. 2014, Dunlop and Corbera 2016). This includes both enforcement of project 
boundaries and monitoring of carbon and biodiversity. Monitoring is increasingly coming to include monitoring of community engagement for many REDD+ projects. Many of our respondents described difficulties in enforcing boundaries within allegedly protected REDD+ project areas. Enforcement is the ability of those running a REDD+ project to control forest-cover change related activities within the boundaries of their project.

As one stakeholder who had been working at the national level for many years put it:

From what I've seen there are three reasons why forest loss happens. One-planned deforestation and conversion to plantations, two- legal activities within concession areas, and three- lack of enforcement where you have encroachment or illegal logging... the government needs to step up enforcement. Respondent ID 10399.

Maintaining capacity for governing and enforcing project boundaries is essential to achieve project success to prevent widespread encroachment and forest degradation. However, a lack of ability to enforce boundaries of protected forest areas, such as REDD+ projects, is one of the challenges mentioned in both the literature (Gaveau et al. 2013, Enrici and Hubacek 2016) and frequently by our respondents. Enforcing boundaries of protected forest areas is something that is a problem in Indonesia for both REDD+ activities as well as national parks (Yuliani et al. 2010, Murdiyarso et al. 2011, Indonesia Ministry of Forestry 2014). The lack of ability to enforce project boundaries often manifests as illegal encroachment into project areas. Furthermore, local authorities do not always act to stop encroachment, demonstrating a lack of support for projects. Such lack of support from authorities was reported by respondents as either failure to approve and enforce project boundaries, failing to take action against encroachers, or collusion of the authorities with encroachers.

One stakeholder, a project organizer whose project faces agricultural encroachment, illegal logging, and intentionally set fires said:

The police won't do anything, really they should be trying to enforce themselves... there was a road built through our concession two years ago, after our concession was approved, it [gives access for] illegal logging. [The local authority] tells people he owns the place, and they pay him to work here. Now those illegal loggers want [us] to pay them to go elsewhere. His son is a policeman here. They know it's supposed to be our concession... If we want to stop them, where can we go? Respondent ID 10390.

In the cases of our study sites, and elsewhere (Gaveau et al. 2007, 2013), encroachment has become substantial and continues to grow over time. In some cases, smallholder palm oil encroachers claim to have been sold permits for the land, and identification of who sells the permits has been elusive. Other of these smallholders are encouraged by large palm oil companies bordering project sites to encroach on the project concession. Once these smallholders have gained access to the area, they quickly deforest patches of the project area and build housing for themselves. When confronted by project organizers, they refuse to leave and retaliate if further action is taken.
One project organizer put it like this:

They're selling the land in our concession. And we've asked some of these people, "Oh, we bought the land. What can you show us?" And the only thing they can show us is that they paidmoney to somebody. Resondent ID 10387.

Project organizers are not willing to engage in such a conflict, and without support from local authorities, they are left without any avenue for recourse. One project organizer explained it like this:

On our land, we have 400 families that have arrived since $2008 . .$. they're taking up over 5000 hectares. They have churches, rice paddies, [a store]... how are we supposed to get rid of them? The authorities won't do anything. Respondent ID 10422.

Additionally, if a REDD+ project is operating as an ERC, the company that is running the project must first get approval from the central government for the license and then have the boundaries of the project approved, also by the central government. Once this happens, the local government must also then reapprove the boundaries set out by the project organizers and the central government. In some cases, it has been reported by project organizers that local authorities have been slow or reluctant to do this. Some stakeholders from our research have suggested that this reluctance happens because of payments to authorities made by encroachers and a desire by authorities for payments from project organizers.

During data collection, encroachment in the project sites and in other protected areas was observed in a number of ways: illegal logging, artisanal mining, and palm oil encroachment by both smallholders and large companies. Often encroachment can harm the community and furthermore presents challenges for a REDD+ project's desired outcomes. It is also rarely halted by local authorities, who may have different plans for the area other than what has been designated by the central government. Local authorities are susceptible to corruption and often will accept bribes from encroachers.

As one of our respondents described it:

The community that has been there for a long time welcomes our help to stop [the illegal logging] because in the old days, they could control who would take [from the forest]. Now there's police operating with the illegal loggers. So if somebody [from the village] doesn't cooperate, they're put in jail. In fact, they actually put somebody from the village in jail because they refused to [work with the] illegal loggers and then confiscated [the community member's] timber, took it and sold it. Respondent ID 10436.

Many respondents report that if facilitators of a REDD+ project want help from local authorities in enforcing their project area, those authorities often want a bribe, which many projects are either unwilling or unable to give. Lack of ability to enforce boundaries and encroachment was seen in all three case study sites.

Furthermore, to demonstrate that a project is effectively maintaining or improving carbon stocks and biodiversity levels, 
it is necessary to have a monitoring system in place. Monitoring, reporting, and verification (MRV) is essential for a REDD+ project to overcome challenges, assess the impact of policies on the ground, avoid unintended consequences, and prove to other stakeholders, particularly funders, that they are having a net positive benefit for carbon sequestration and biodiversity (de Sassi et al. 2015). Although monitoring technology currently exists for meeting the needs of REDD+ (Goetz et al. 2015), not all countries have begun taking advantage of this technology. Many countries and projects in Indonesia have yet to establish baselines for carbon stock and for potential forest-cover loss under business as usual scenarios (Virah-Sawmy et al. 2015). Many countries and projects are still figuring out exactly how to set up an MRV system (Ochieng et al. 2016).

As one stakeholder put it:

There is no one MRV that's been agreed on by all. How to [do it] and who will decide the MRV system in Indonesia, it's still a question at the national level. Respondent ID 10413.

Another stakeholder put it this way:

We want to change the monitoring system, to do training and develop a standard for monitoring and it is not easy. Respondent ID 10393.

Monitoring of carbon stocks can be done in a number of ways, i.e., through combining both remote sensing and communitybased monitoring or monitoring by an independent agency. Community-based monitoring of forest cover over a number of years has proven to be accurate, cost-effective, and to increase community involvement in other aspects of forest management (Brofeldt et al. 2014). In cases in which the community may not have enough members to monitor a very large REDD+ concession, other methods for monitoring must be used. Independent monitoring, such as that carried out using a carbon offset standard or remote sensing analysis, allows verification that projects are achieving what they say they are. Monitoring must also include community involvement and biodiversity criteria of projects to ensure that fair and equitable practices are being undertaken and that there is some assurance of effectiveness and the long-term viability of a project (Panfil and Harvey 2015, de Sassi et al. 2015). Numerous carbon offset standards, guidelines for monitoring, reporting, and verifying forest carbon projects through independent entities have been developed (Kollmuss et al. 2008).

All three of the case study sites face challenges with governing capacity, particularly with enforcing project boundaries. The Rimba Raya project has experienced some encroachment, from both illegal loggers as well as palm oil. Rimba Raya has been able to keep encroachment at a level low enough to obtain carbon certification, but it is a significant enough problem to warrant constant attention. Lack of support from local officials can be seen by the instances of encroachment that occur, and land use conflicts are endemic to the area (Indriatmoko et al. 2014). For example, illegal loggers enter the area, perhaps after purchasing "permission" to enter the area from someone not involved with Rimba Raya but connected to the local authorities. When approached by the project and asked to leave, they expect to be compensated for the fee they have paid for access to the area. The palm oil operation bordering Rimba Raya has also encroached on the concession and reportedly encouraged community members to do so as well, in part supported by the local authorities failure to approve the border of the concession, as outlined by the project organizers and approved by the Ministry of Forestry. Beyond this, some local authorities have used part of the area inside the Rimba Raya concession for their own use, degrading the forest in the process.

In terms of the monitoring component of governance capacity, Rimba Raya is the only one out of the three projects observed for our research that is currently being evaluated by an independent agency. In 2015, Rimba Raya received VCS and Community, Climate, Biodiversity certification, which included assessment of carbon stock, biodiversity levels, and their relationship with the communities on their concession (Infinite Earth 2015). The Community Climate and Biodiversity standard and Voluntary Carbon Standard are two monitoring entities recognized by the international carbon markets. The Voluntary Carbon Standard focuses on evaluating projects for reduced greenhouse gas emissions but partners with other standard verification schemes, such as Community Climate and Biodiversity, to provide projects with certification for carbon cobenefits. The Community Climate and Biodiversity standards are used to evaluate project design (as opposed to verifying carbon stocks) by the three main components of community, climate, and biodiversity while also assessing environmental and economic sustainability. Although there have been concerns regarding the limitations of Community Climate and Biodiversity (Melo et al. 2014), this kind of monitoring and verification is essential for donors, including the developing carbon market and interested stakeholders at all levels. These certifications give the project credibility when dealing with donors and the press. Neither of the other two projects had achieved certification by a carbon offset standard entity at the time of our research. Although it is possible that many REDD+ projects have successfully achieved carbon sequestration goals and cobenefits, having the certification of an independent monitoring agency such as VCS allows a project to demonstrate verified results to stakeholders of all categories (including funders and policymakers).

In the case of Kapuas Hulu, the challenge with enforcement of project boundaries differs from the other two case study sites. Strong relationships and a project built collaboratively with the local communities have meant that encroachment has not been reported as an issue for the project. Most of the project area is recognized community forest that has been established for a long time, and forest access and use are regulated by local communities. However, although the communities maintain authority over the project site, there is a potential challenge for the Kapuas Hulu project because of the fact that the community forest overlaps with a palm oil concession. This kind of overlap is common throughout Indonesia and is problematic for many forest governance scenarios (Steni and Hadad 2012, Stevens et al. 2014). The company that holds the license has tried to gain community approval to activate their license. Although the legality of whether or not they can activate the concession is unclear, often palm oil companies want community approval to avoid conflict and violence. Many of the community leaders in Kapuas Hulu and community members themselves are against palm oil development. They report having seen palm oil destroy nearby 
community forests where relatives live, promises made by the palm oil companies are not kept, and sources of livelihood are then gone, taken over by palm oil. Although many of our respondents reported that the palm oil company will not activate their license without support of the forest communities of Kapuas Hulu, the scenario does make tenure over their forests vulnerable from a legal standpoint (Contreras-Hermosilla et al. 2005).

Encroachment remains a challenge for Harapan in achieving their goal of protecting and restoring the forest in their concession. There is a record of land-use conflicts in the area and evidence that such conflicts may be increasing (Beckert et al. 2014). Although similar in nature to the challenges faced by Rimba Raya, the encroachment in Harapan is more widespread. Harapan has experienced encroachment on a total of 18,758 ha or $19.14 \%$ of the concessions total 98,000 ha, and at an average encroachment rate of $2623 \mathrm{ha} /$ year, this could potentially leave the entire project area deforested by encroachment over the next 40 years (Silalahi and Erwin 2015). There has also sometimes been a lack of support by local officials, as in the case of Rimba Raya. There are reported instances of the local authorities colluding with encroachers or expecting unofficial incentives from project organizers, something not allocated for in a budget at least partially funded by private entities and international aid agencies. Encroachment has occurred primarily by small holders from other areas of Indonesia. Often individuals are sold palm oil permits illegally for the area inside of Harapan. Without support from local authorities, Harapan is left to their own devices to deal with the encroachment. Many of these palm oil smallholders move in quickly and build makeshift homes on the land where they are planting. Once they have done this, it is nearly impossible for them to be ejected from the area by the project organizers.

\section{Carbon sequestration and biodiversity preservation}

Although the three criteria discussed are components of REDD+ projects that contribute to effectiveness, carbon sequestration and biodiversity preservation are outcome criteria, without which a project cannot claim to have achieved success with respect to the objectives of REDD+. All criteria discussed until this point can have an impact on how projects are able to achieve effectiveness in carbon sequestration and biodiversity preservation. Many stakeholders and the literature cited have identified the previous criteria of funding, community engagement, and governance capacity as important. It is even possible that some stakeholders might even argue that without any one of these, or all of them, a project cannot be described as effective. However, because the primary goal of REDD+ is to reduce emissions from deforestation and forest degradation, effectiveness is absolutely necessary in this area and thus is referred to as an outcome criterion. And although the other criteria may have some impact on carbon sequestration and forest cover, it is possible that a project may effectively prevent forest degradation or lead to afforestation, without those criteria being met. However, it could not be argued that a project is effectively working toward REDD+ goals unless forest loss is being prevented or forest restoration is occurring. Furthermore, to demonstrate that this has occurred there must be some kind of verified independent auditing for the project site.

The initial goal of REDD+ was to lower carbon emissions by reducing deforestation and forest degradation, and shortly thereafter, biodiversity preservation was acknowledged as an important component (Gibbs et al. 2007). It is also important to acknowledge the importance of peatlands in the context of carbon sequestration. Peatland forests play an important role in carbon sequestration (Page et al. 2011), are crucial for biodiversity preservation (Koh et al. 2011), and are vulnerable to degradation (Yu et al. 2011). Of the three REDD+ project sites, Rimba Raya (Indriatmoko et al. 2014) and Kapuas Hulu (Labrière et al. 2016) are documented peat forests. This is also important to note because peatlands are an important and sometimes unacknowledged source of additional carbon sequestration (van der Werf et al. 2009).

The Rimba Raya project has demonstrated effectiveness in carbon sequestration, biodiversity preservation, and community engagement for the periods during which they have been monitored independently by the Verified Carbon Standard, i.e., from July 2009 through June 2014, (SCS 2013, ESI 2015). As one of the reports states, "...emission reductions from the Rimba Raya Biodiversity Reserve project for the period of 1 July 2009 to 30 June 2010 amount to 2,181,352 tonnes of CO2 equivalent after a $10 \%$ buffer pool deduction amounting to 242,373 tonnes of $\mathrm{CO} 2$ equivalent is taken into consideration.” (SCS 2013:2). Despite what challenges the project has faced, Rimba Raya has obtained funding, engaged with communities, and demonstrated effectiveness as a REDD+ project through the independent monitoring of their community engagement, carbon sequestration, and biodiversity preservation.

Harapan Rainforest was previously designated as a timber concession, and so although it stands to reason that the carbon sequestration and biodiversity levels have improved there since PT REKI obtained the ERC license, it is not possible to confirm any changes in carbon stock or biodiversity levels. The lack of ability to enforce project boundaries and the absence of independent monitoring indicates uncertainty regarding quantitative changes regarding carbon and biodiversity. So although it could be argued that all three sites have achieved some level of carbon sequestration and biodiversity preservation, at the very least preventing legal palm oil or logging to occur on project sites, it is impossible to demonstrate because monitoring has not been undertaken. Without independent monitoring of the sites, it is difficult, if not impossible, to demonstrate how carbon and biodiversity levels have changed since the projects began.

\section{CONCLUSIONS AND DISCUSSION}

Since the introduction of REDD+, some key questions and concerns have been expressed in the literature. In particular, how will REDD+ be implemented across scales ranging from international policies and frameworks, to national-level policies, and finally locally on the ground (Sills et al. 2014, Sunderlin et al. 2014a, b). More specifically, how will forest management change as a result of the introduction of REDD+? It is possible that REDD+ could cause recent movements toward decentralized forest management to shift back toward more centralized forest management, to the detriment of communities and forests (Phelps et al. 2010). The results of our research indicate that in Indonesia's already decentralized system, the authority over forests has mostly remained in the hands of some local stakeholders but not always with local forest communities. Often, that authority is more likely to rest with local-level government officials (Enrici 
and Hubacek 2016). However, it is possible that REDD+ is offering an opportunity to shift that form of decentralized forest management, not into recentralized forest management, but into project-level forest governance in some instances. Whether local communities are being empowered by this shift, is still a question that warrants further research. Moreover, there are indications that some policies seem to be biased toward international, rather than national-level concerns about equity (Di Gregorio et al. 2013). As more projects continue to develop, there is a need for understanding who the winners and losers are in REDD+ (Campbell 2009, Luttrell et al. 2013, 2014), particularly as projects move from policy to implementation. Although our research may begin to answer some of these questions by presenting case studies from three REDD+ projects currently underway, further research is still needed to see how communities and other stakeholders are affected in the long term. Another major question for REDD+ is whether it will deliver on its promised benefits of carbon sequestration and biodiversity preservation (Gardner et al. 2012, Murray et al. 2014) or if it will simply be another conservation fad (Redford et al. 2013, Lund et al. 2017). Answering this will require further investigation into $\mathrm{REDD}+$ projects as they develop, along with monitoring the rates of deforestation and forest degradation. The results of our research raise some concern that REDD+ may be failing to materialize in Indonesia because of financial constraints and the complexities of the Indonesian context. More recently concerns have turned to why REDD+ may not be delivering on its promised benefits (Fletcher et al. 2016, Angelsen et al. 2017). One way to address this question might be to further investigate the challenges, such as corruption, encroachment, and lack of funding, which have been identified in our research.

Turnhout et al. (2017:1) suggested "that the future of REDD+ may lie not in one conceptualization coming to dominate, but rather in co-existence of heterogeneous practices," which reflects the multidimensional manifestations of REDD+ in Indonesia. We suggest that although diversity among projects is helpful for REDD+ in a context as complex as Indonesia, it is necessary and urgent for independent, standardized, and verifiable monitoring practices to be established. Monitoring capabilities to make REDD+ operational already exist, and more complex monitoring capabilities will soon be available in countries where REDD+ is being implemented (Goetz et al. 2015). Monitoring is necessary for answering many of these questions because established baselines combined with effective monitoring are prerequisites for demonstrating carbon sequestration, or emission prevention through additionality, biodiversity preservation, and even proper community involvement (Herold and Skutsch 2009, de Sassi et al. 2015). Establishing a baseline for proper monitoring of carbon stocks and deforestation rates allows for measurement of future rates of change, and remote sensing provides one of the most efficient and rapid ways to achieve this (Pelletier and Goetz 2015). Monitoring of forest cover can, to a large extent, be done through remote sensing (Goetz et al. 2015), but even with the technological assistance of such methods, remote sensing still requires ground truthing, and thorough biodiversity and community monitoring require actual site visits. Many countries undertaking REDD+ may have the technology for monitoring, but have yet to implement a monitoring, reporting, and verification mechanism (Ochieng et al. 2016). Despite the importance of cobenefits, such as community engagement and biodiversity, and the necessity to monitor them, very little attention to date has been given to monitoring cobenefits (Vijge et al. 2016). Furthermore, the diversity of projects and their funding sources in Indonesia means that not all demonstration activities need or choose to adopt safeguards for ensuring cobenefits that have been created by entities such as the UN. Assessing the criteria that can help a project to effectively sequester carbon and preserve biodiversity offers the opportunity to highlight the major challenges and opportunities for REDD+ projects in Indonesia and potentially elsewhere. It is helpful to reflect on the similarities and differences among project sites for each criterion.

In terms of funding, both Rimba Raya and Kapuas Hulu have established very different, yet stable funding situations. Rimba Raya's process of establishing their REDD+ project and selling carbon credits on the market provides a useful example of how a REDD+ project could be run, yet at the time of this research, this was the exception rather than the rule in Indonesia. Kapuas Hulu is representative of a number of other REDD+ projects throughout Indonesia that are started by NGOs or institutions that may already have funding available. However, the challenge that long-term funding presents for Harapan seems to be representative of the experience of many of our interviewees from outside the three case study sites, as well as the literature (UNREDD Programme 2013, Dixon and Challies 2015).

Community engagement varies at each site, though Kapuas Hulu presents an example of how a project might look when designed with collaborative management techniques that have been successful for ecosystem management practices in other instances (Fisher 1995, Daniels and Walker 1996, Schusler et al. 2003). Despite stakeholder fatigue, Rimba Raya has also developed a working relationship with verified cobenefits for communities within the project sites. Harapan Rainforest faces a challenging situation with their communities, in good part because of the conflict and marginalization of those communities before the project began.

In spite of tenure challenges, enforcement of project boundaries as a component of governance capacity could be argued to be the strongest in Kapuas Hulu because of collaboration with the forest communities who govern the forest area included in the project. Although both Rimba Raya and Harapan face challenges with having governance capacity, in terms of boundary enforcement and the ability to prevent unsanctioned deforestation on their project sites, based on the amount of encroachment, the problem seems to be significantly worse for Harapan. This may at least partially have been a larger problem because the project area was being encroached upon before Harapan's ERC was granted in 2008 (Silalahi and Erwin 2015). Harapan's challenges in this regard could also potentially be attributed to, or compounded by, challenges with other criteria. Community involvement has been challenging, weakening the ability of those communities to enforce boundaries as is seen with Kapuas Hulu. Moreover, Harapan lacked funding and flexibility to use funds to come up with alternative strategies for dealing with encroachment.

Without monitoring, the other aspect of governance capacity, it is hard for any project to claim improvements in forest cover, community benefits, or biodiversity levels. Despite this, independent monitoring may not always make sense for every 
project, as in the case of the Kapuas Hulu project in which independent monitoring would be expensive and is unnecessary for securing funding. If a national-level agency is established for monitoring forest cover, this will help with monitoring the projects. This is a distinct possibility because the technology for proper monitoring of REDD+ currently exists, and is going to continue to improve in coming years (Goetz et al. 2015).

Carbon stock maintenance or improvement and biodiversity preservation are essential goals for any REDD+ project. They cannot be demonstrated without proper baselines and monitoring. Rimba Raya is the only project to demonstrate verified results. However, having an ERC license such as Harapan's could be argued to be an improvement over other kinds of forest-use licenses, which, based on the evidence from other production forest areas (Margono et al. 2012), would likely result in significant forest-cover loss. Despite this, as is clear from the numbers regarding Harapan's encroachment, having long-term effectiveness in improving forest cover in REDD+ projects will likely require attention to the other criteria, such as funding, community involvement, and governing capacity. Challenges toward the inputs of financing, community involvement, governing capacity, and monitoring can compound and ultimately may prevent a project from effectively improving forest carbon stocks and biodiversity preservation.

Responses to this article can be read online at: http://www.ecologyandsociety.org/issues/responses. $\mathrm{php} / 9805$

\section{Acknowledgments:}

This research was based on two years of fieldwork funded by the Fulbright US Student Program and the University of Maryland. Thanks to Julie Silva, Dr. Achmand Nurmandi, Dr. Rahmawati Husein, Dr. Eko Purnomo, and to Universitas Muhammadiah Yogyakarta.

\section{LITERATURE CITED}

Agrawal, A., and A. Angelsen. 2009. Using community forest management to achieve REDD+ goals. Page 201-213 in A. Angelsen, editor. Realising REDD+: national strategy and policy options. Center for International Forestry Research, Bogor, Indonesia. [online] URL: https://www.cifor.org/publications/ pdf_files/Books/BAngelsen0902.pdf

Agung, P., G. Galudra, M. van Noordwijk, and R. Maryani. 2014. Reform or reversal: the impact of REDD+ readiness on forest governance in Indonesia. Climate Policy 14:748-768. http://dx. doi.org/10.1080/14693062.2014.941317

Angelsen, A., M. Brockhaus, A. E. Duchelle, A. Larson, C. Martius, W. D. Sunderlin, L. Verchot, G. Wong, and S. Wunder. 2017. Learning from REDD+: a response to Fletcher et al. Conservation Biology 31(3):718-720. http://dx.doi.org/10.1111/ cobi. 12933

Angelsen, A., and T. K. Rudel. 2013. Designing and implementing effective REDD+ policies: a forest transition approach. Review of Environmental Economics and Policy 7(1):91-113. http://dx.doi. org/10.1093/reep/res022

Barr, C. M., I. A. P. Resosudarmo, A. Dermawan, J. McCarthy, M. Moeliono, and B. Setiono, editors. 2006. Decentralization of forest administration in Indonesia: implications for forest sustainability, economic development, and community livelihoods. Center for International Forestry Research, Bogor, Indonesia. [online] URL: http://www.cifor.org/publications/pdf files/Books/ BBarr0601.pdf

Barrett, K., and A. Goldstein. 2015. Norway, Germany, UK pledge $\$ 5$ billion to combat tropical deforestation. Ecosystem Marketplace, 30 November. [online] URL: http://www. ecosystemmarketplace.com/articles/norway-germany-uk-pledge-5billion-to-combat-tropical-deforestation/

Bayrak, M. M., and L. M. Marafa. 2016. Ten years of REDD+: a critical review of the impact of REDD+ on forest-dependent communities. Sustainability 8(7):620. http://dx.doi.org/10.3390/ $\underline{\text { su} 8070620}$

Beaudoin, G., S. Rafanoharana, M. Boissière, A. Wijaya, and W. Wardhana. 2016. Completing the picture: importance of considering participatory mapping for REDD+ measurement, reporting and verification (MRV). PloS one 11(12):e0166592. http://dx.doi.org/10.1371/journal.pone.0166592

Beckert, B., C. Dittrich, and S. Adiwibowo. 2014. Contested land: an analysis of multi-layered conflicts in Jambi Province, Sumatra, Indonesia. Austrian Journal of South-East Asian Studies 7 (1):75-92. http://dx.doi.org/10.14764/10.ASEAS-2014.1-6

Bernard, H. R. 2006. Research methods in anthropology: qualitative and quantitative approaches. Altamira, Lanham, Maryland, USA.

Bolin, A., and D. T. Tassa. 2012. Exploring climate justice for forest communities engaging in REDD+: experiences from Tanzania. Forum for Development Studies 39:5-29. http://dx.doi. org/10.1080/08039410.2011.635380

Brofeldt, S., I. Theilade, N. D. Burgess, F. Danielsen, M. K. Poulsen, T. Adrian, T. N. Bang, A. Budiman, J. Jensen, A. E. Jensen, Y. Kurniawan, S. B. L. LÃ Noordwijk, S. Rahayu, E. Rutishauser, D. Schmidt-Vogt, Z. Warta, and A. Widayati. 2014. Community monitoring of carbon stocks for REDD+: does accuracy and cost change over time? Forests 5(8):1834-1854. http://dx.doi.org/10.3390/f5081834

Broich, M., M. Hansen, F. Stolle, P. Potapov, B. A. Margono, and B. Adusei. 2011. Remotely sensed forest cover loss shows high spatial and temporal variation across Sumatera and Kalimantan, Indonesia 2000-2008. Environmental Research Letters 6(1):14010. [online] URL: http://iopscience.iop.org/article/10.1088/1748-9326/6/1/014010/meta

Buergin, R. 2016. Ecosystem restoration concessions in Indonesia: conflicts and discourses. Critical Asian Studies 48 (2):278-301. http://dx.doi.org/10.1080/14672715.2016.1164017

Burgess, N. D., B. Bahane, T. Clairs, F. Danielsen, S. Dalsgaard, M. Funder, N. Hagelberg, P. Harrison, C. Haule, K. Kabalimu, F. Kilahama, E. Kilawe, S. L. Lewis, J. C. Lovett, G. Lyatuu, A. R. Marshall, C. Meshack, L. Miles, S. A.H. Milledge, P. K. T. 
Munishi, E. Nashanda, D. Shirima, R. D. Swetnam, S. Willcock, A. Williams, and E, Zahabu. 2010. Getting ready for REDD+ in Tanzania: a case study of progress and challenges. Oryx 44 (3):339-351. http://dx.doi.org/10.1017/S0030605310000554

Busch, J. 2013. Supplementing REDD+ with biodiversity payments: the paradox of paying for multiple ecosystem services. Land Economics 89(4):655-675. http://dx.doi.org/10.3368/ $\underline{\text { le.89.4.655 }}$

Butler, R. A., L. P. Koh, and J. Ghazoul. 2009. REDD in the red: palm oil could undermine carbon payment schemes. Conservation Letters 2(2):67-73. http://dx.doi.org/10.1111/j.1755-263X.2009.00047. $\underline{x}$

Campbell, B. M. 2009. Beyond Copenhagen: REDD+, agriculture, adaptation strategies and poverty. Global Environmental Change 19(4):397-399. http://dx.doi.org/10.1016/ j.gloenvcha.2009.07.010

Carbon Market Watch. 2013. REDD. Carbon Market Watch, Brussels, Belgium. [online] URL: https://carbonmarketwatch. org/2013/04/09/redd/

Carlson, K. M., L. M. Curran, G. P. Asner, A. M. Pittman, S. N. Trigg, and J. M. Adeney. 2013. Carbon emissions from forest conversion by Kalimantan oil palm plantations. Nature Climate Change 3(3):283-287. http://dx.doi.org/10.1038/nclimate1702

Chao, S. 2012. Forest peoples: numbers across the world. Forest Peoples Programme, Moreton-in-Marsh, UK. [online] URL: http://www.forestpeoples.org/sites/fpp/files/publication/2012/05/forestpeoples-numbers-across-world-final_0.pdf

Charmaz, K. 2006. Constructing grounded theory: a practical guide through qualitative analysis. Sage, Thousand Oaks, California, USA.

Charmaz, K., and L. Belgrave. 2002. Qualitative interviewing and grounded theory analysis. Pages 347-367 in J. F. Gubrium and J. A. Holstein, editors. Handbook of interview research: the complexity of the craft. Sage, Thousand Oaks, California.

Colchester, M., P. Anderson, A. Y. Firdaus, F. Hasibuan, and S. Chao. 2011. Human rights abuses and land conflicts in the PT Asiatic Persada concession in Jambi: report of an independent investigation into land disputes and forced evictions in a palm oil estate. HUMA, Sawit Watch, Forest Peoples Programme, Jakarta, Indonesia, Bogor, Indonesia, Moreton-in-Marsh, UK. [online] URL: http://www.forestpeoples.org/sites/default/files/ publication/2011/11/final-report-pt-ap-nov-2011-low-res-1.pdf

Contreras-Hermosilla, A., and C. Fay. 2005. Strengthening forest management in Indonesia through land tenure reform: issues and framework for action. Forest Trends, Washington, D.C., USA. [online] URL: http://www.forest-trends.org/documents/files/ doc 107.pdf

Corbin, J., and A. Strauss. 2007. Basics of qualitative research: techniques and procedures for developing grounded theory. Sage, Thousand Oaks, California, USA. http://dx.doi. org/10.4135/9781452230153

Creed, A., and S. Nakhooda. 2011. REDD+ finance delivery: lessons from early experience. Climate finance policy brief. Heinrich B öll Stiftung and Overseas Development Institute,
Washington, D.C., London, UK. [online] URL: https://www.odi. org/sites/odi.org.uk/files/odi-assets/publications-opinion-files/7481. pdf

Curran, L. M., S. N. Trigg, A. K. McDonald, D. Astiani, Y. M. Hardiono, P. Siregar, I. Caniago, and E. Kasischke. 2004. Lowland forest loss in protected areas of Indonesian Borneo. Science 303(5660):1000-1003. http://dx.doi.org/10.1126/science.1091714

Daniels, S. E., and G. B. Walker. 1996. Collaborative learning: improving public deliberation in ecosystem-based management. Environmental Impact Assessment Review 16(2):71-102. http://dx. doi.org/10.1016/0195-9255(96)00003-0

Danielsen, F., T. Adrian, S. Brofeldt, M. van Noordwijk, M. K. Poulsen, S. Rahayu, E. Rutishauser, I. Theilade, A. Widayati, T. Nguyen Bang, A. Budiman, M. Enghoff, A. E. Jensen, Y. Kurniawan, Q. Li, Z. Mingxu, D. Schmidt-Vogt, S. Prixa, V. Thoumtone, Z. Warta, and N. Burgess.. 2013. Community monitoring for REDD+: international promises and field realities. Ecology and Society 18(3):41. http://dx.doi.org/10.5751/ ES-05464-180341

De Sy, V., M. Herold, F. Achard, G. P. Asner, A. Held, J. Kellndorfer, and J. Verbesselt. 2012. Synergies of multiple remote sensing data sources for REDD+ monitoring. Current Opinion in Environmental Sustainability 4(6):696-706. http://dx.doi.org/10.1016/ j.cosust.2012.09.013

Decrop, A. 1999. Triangulation in qualitative tourism research. Tourism Management 20(1):157-161. http://dx.doi.org/10.1016/ $\underline{\mathrm{S} 0261-5177(98) 00102-2}$

de Sassi, C., S. Joseph, A. B. Bos, A. E. Duchelle, A. Ravikumar, and M. Herold. 2015. Towards integrated monitoring of REDD+. Current Opinion in Environmental Sustainability 14:93-100. http://dx.doi.org/10.1016/j.cosust.2015.04.003

Di Gregorio, M., M. Brockhaus, T. Cronin, E. Muharrom, L. Santoso, S. Mardiah, and M. Büdenbender. 2013. Equity and REDD+ in the media: a comparative analysis of policy discourses. Ecology and Society 18(2):39. http://dx.doi. org/10.5751/ES-05694-180239

Dixon, R., and E. Challies. 2015. Making REDD+ pay: shifting rationales and tactics of private finance and the governance of avoided deforestation in Indonesia. Asia Pacific Viewpoint 56 (1):6-20. http://dx.doi.org/10.1111/apv.12085

Dunlop, T., and E. Corbera. 2016. Incentivizing REDD+: how developing countries are laying the groundwork for benefitsharing. Environmental Science and Policy 63:44-54. http://dx.doi. org/10.1016/j.envsci.2016.04.018

Edwards, D. P., L. P. Koh, and W. F. Laurance. 2012. Indonesia's REDD+ pact: saving imperilled forests or business as usual? Biological Conservation 151(1):41-44. https://doi.org/10.1016/j. biocon.2011.10.028

Enrici, A., and K. Hubacek. 2016. Business as usual in Indonesia: governance factors effecting the acceleration of the deforestation rate after the introduction of REDD+. Energy, Ecology and Environment 1(4):183-196. http://dx.doi.org/10.1007/s40974-016-0037-4

Environmental Services, Inc. (ESI). 2015. Verification report for the Rimba Raya Biodiversity Reserve Project. Infinite Earth, Hong 
Kong. [online] URL: http://database.v-c-s.org/sites/v-c-s.org/ files/061-RimbaRaya $\% 20 \mathrm{VCS} \% 20 \mathrm{CCB} \% 203 \mathrm{rd} \% 20$ Monitoring $\%$ 20Period $\% 20$ Verification $\% 20$ Report v03-20150824\%20(2).pdf

Fisher, R. J. 1995. Collaborative management of forests for conservation and development. International Union for Conservation of Nature, World Wide Fund for Nature, Gland, Switzerland. [online] URL: http://www.mekonginfo.org/assets/ midocs/0003347-environment-collaborative-management-of-forestsfor-conservation-and-development.pdf

Fletcher, R., W. Dressler, B. Büscher, and Z. R. Anderson. 2016. Questioning REDD+ and the future of market-based conservation. Conservation Biology 30(3):673-675. http://dx.doi. org/10.1111/cobi.12680

Fry, B. P. 2011. Community forest monitoring in REDD+: the 'M' in MRV? Environmental Science and Policy 14(2):181-187. https://doi.org/10.1016/j.envsci.2010.12.004

Galudra, G., M. Van Noordwijk, S. Suyanto, I. Sardi, U. Pradhan, and D. Catacutan. 2011. Hot spots of confusion: contested policies and competing carbon claims in the peatlands of Central Kalimantan, Indonesia. International Forestry Review 13 (4):431-441. http://dx.doi.org/10.1505/146554811798811380

Gardner, T. A., N. D. Burgess, N. Aguilar-Amuchastegui, J. Barlow, E. Berenguer, T. Clements, F. Danielsen, J. Ferreira, W. Foden, V. Kapos, S. M. Khan, A. C. Lees, L. Parry, R. M. RomanCuesta, C. B. Schmitt, N. Strange, I. Theilade, and C. G.Vieira. 2012. A framework for integrating biodiversity concerns into national REDD+ programmes. Biological Conservation 154:61-71. http://dx.doi.org/10.1016/j.biocon.2011.11.018

Gaveau, D. L. A., M. Kshatriya, D. Sheil, S. Sloan, E. Molidena, A. Wijaya, S. Wich, M. Ancrenaz, M. Hansen, M. Broich, M. R. Guariguata, P. Pacheco, P. Potapov, S. Turubanova, and E. Meijaard. 2013. Reconciling forest conservation and logging in Indonesian Borneo. PloS one 8(8):e69887. http://dx.doi. org/10.1371/journal.pone.0069887

Gaveau, D. L. A., D. Sheil, M. A. S. Husnayaen, S. Arjasakusuma, M. Ancrenaz, P. Pacheco, and E. Meijaard. 2016. Rapid conversions and avoided deforestation: examining four decades of industrial plantation expansion in Borneo. Scientific Reports 6:32017. http://dx.doi.org/10.1038/srep32017

Gaveau, D. L. A., H. Wandono, and F. Setiabudi. 2007. Three decades of deforestation in southwest Sumatra: have protected areas halted forest loss and logging, and promoted re-growth? Biological Conservation 134(4):495-504. http://dx.doi.org/10.1016/ j.biocon.2006.08.035

Gibbs, H. K., S. Brown, J. O. Niles, and J. A. Foley. 2007. Monitoring and estimating tropical forest carbon stocks: making REDD a reality. Environmental Research Letters 2(4):45023. http://dx.doi.org/10.1088/1748-9326/2/4/045023

Goetz, S., M. Hansen, R. A. Houghton, W. Walker, N. T. Laporte, and J. Busch. 2015. Measurement and monitoring for REDD+: the needs, current technological capabilities, and future potential. Working Paper \#392. Center for Global Development, Washington, D.C., USA. http://dx.doi.org/10.2139/ssrn.2623076
Hagan, J. M., and A. A. Whitman. 2006. Biodiversity indicators for sustainable forestry: simplifying complexity. Journal of Forestry 104(4):203-210.

Hamrick, K., and A. Goldstein. 2015. Ahead of the curve: state of the voluntary carbon markets 2015. Forest Trends, Washington, D.C., USA. [online] URL: http://forest-trends.org/releases/ uploads/SOVCM2015 FullReport.pdf

Hansen, M. C., P. V. Potapov, R. Moore, M. Hancher, S. A. Turubanova, A. Tyukavina, D. Thau, S. V. Stehman, S. J. Goetz, T. R. Loveland, A. Kommareddy, A. Egorov, L. Chini, C. O. Justice, and J. R. G. Townshend. 2013. High-resolution global maps of 21st-century forest cover change. Science 342 (6160):850-853. http://dx.doi.org/10.1126/science.1244693

Hayes, T., and L. Persha. 2010. Nesting local forestry initiatives: revisiting community forest management in a REDD+ world. Forest Policy and Economics 12(8):545-553. http://dx.doi. org/10.1016/j.forpol.2010.07.003

Herold, M., and M. Skutsch. 2009. Measurement, reporting and verification for REDD+: objectives, capacities and institutions. Pages 84-100 in A. Angelsen, editor. Realising REDD+: national strategy and policy options. Center for International Forestry Research, Bogor, Indonesia. [online] URL: http://www.cifor.org/ publications/pdf files/Books/BAngelsen090207.pdf

Holloway, V., and E. Giandomenico. 2009. The history of REDD policy. Carbon Planet white paper. Carbon Planet, Adelaide, Australia. [online] URL: http://redd.unfccc.int/uploads/2 164 redd_20091216_carbon_planet the history of redd carbon_planet. pdf

Howell, S. 2015. Politics of appearances: some reasons why the UN-REDD project in Central Sulawesi failed to unite the various stakeholders. Asia Pacific Viewpoint 56(1):37-47. http://dx.doi. org/10.1111/apv.12081

Indonesia Ministry of Forestry. 2014. Ministry of Forestry statistics 2013. Indonesia Ministry of Forestry, Jakarta, Indonesia.

Indonesia REDD+ Task Force (IRTF). 2012. REDD+ national strategy. Indonesian REDD+ Task Force, Jakarta, Indonesia. [online] URL: https://www.unredd.net/documents/un-redd-partnercountries-181/national-redd-strategies-1025/15862-indonesia-nationalredd-strategy.html

Indrarto, G. B., P. Murharjanti, J. Khatarina, I. Pulungan, F. Ivalerina, R. Justitia, N. P. Muhar, I. A. P. Resosudarmo, and E. Muharrom. 2012. The context of REDD+ in Indonesia: drivers, agents and institutions. Center for International Forestry Research, Bogor, Indonesia. [online] URL: http://www.cifor.org/ publications/pdf files/WPapers/WP92Resosudarmo.pdf

Indriatmoko, Y., S. Atmadja, A. D. Ekaputri, and M. Komalasari. 2014. Rimba Raya Biodiversity Reserve Project, Central Kalimantan, Indonesia. In E. O. Sills, S. S. Atmadja, C. de Sassi, A. E. Duchelle, D. L. Kweka, I. A. P. Resosudarmo, and W. D. Sunderlin, editors. REDD+ on the ground: a case book of subnational initiatives across the globe. Center for International Forestry Research, Bogor, Indonesia. [online] URL: https://www. cifor.org/redd-case-book/case-reports/indonesia/rimba-raya-biodiversityreserve-project-central-kalimantan-indonesia/ 
Infinite Earth. 2015. Indonesia's Rimba Raya REDD+ project retains triple gold status for climate, community and biodiversity benefits. Infinite Earth, Hong Kong. [online] URL: https://www. prnewswire.com/news-releases/indonesias-rimba-raya-redd-projectretains-triple-gold-status-for-climate-community-and-biodiversitybenefits-300149497.html

Jagger, P., K. Lawlor, M. Brockhaus, M. F. Gebara, D. J. Sonwa, and I. A. P. Resosudarmo. 2012. REDD+ safeguards in national policy discourse and pilot projects. Pages 301-316 in A. Angelsen, M. Brockhaus, W. D. Sunderlin, and L. Verchot, editors. Analysing REDD+: challenges and choices. Center for International Forestry Research, Bogor, Indonesia. [online] URL: http://www.cifor.org/publications/pdf files/Books/BAngelsen120117. pdf

Johannsdottir, L., and C. McInerney. 2016. Calls for Carbon Markets at COP21: a conference report. Journal of Cleaner Production 124:405-407. http://dx.doi.org/10.1016/j.jclepro.2016.02.094

Jong, N. H. 2015. After only one year, REDD+ agency future is in doubt. 10 January. Jakarta Post. [online] URL: http://www. thejakartapost.com/news/2015/01/10/after-only-one-year-redd-agencyfuture-doubt.html

Kalkuhl, M., O. Edenhofer, and K. Lessmann. 2015. The role of carbon capture and sequestration policies for climate change mitigation. Environmental and Resource Economics 60(1):55-80. http://dx.doi.org/10.1007/s10640-013-9757-5

Kissinger, G., M. Herold, and V. De Sy. 2012. Drivers of deforestation and forest degradation: a synthesis report for REDD+ policymakers. Lexeme Consulting, Vancouver, British Columbia, Canada. [online] URL: https://www.forestcarbonpartnership. org/sites/fcp/files/DriversOfDeforestation.pdf N S.pdf

Koh, L. P., J. Miettinen, S. C. Liew, and J. Ghazoul. 2011. Remotely sensed evidence of tropical peatland conversion to oil palm. Proceedings of the National Academy of Sciences 108 (12):5127-5132. http://dx.doi.org/10.1073/pnas.1018776108

Kollmuss, A., H. Zink, and C. Polycarp. 2008. Making sense of the voluntary carbon market: a comparison of carbon offset standards. WWF Germany, Berlin, Germany. [online] URL: http://www.wwf.de/fileadmin/fm-wwf/Publikationen-PDF/ A Comparison of Carbon Offset Standards lang.pdf

Labrière, N., B. Locatelli, G. Vieilledent, S. Kharisma, I. Basuki, V. Gond, and Y. Laumonier. 2016. Spatial congruence between carbon and biodiversity across forest landscapes of northern Borneo. Global Ecology and Conservation 6:105-120. http://dx. doi.org/10.1016/j.gecco.2016.01.005

Lang, C. 2013. Two contrasting views of the Harapan Rainforest Project, Sumatra, Indonesia. 12 March. REDD Monitor. http:// www.redd-monitor.org/2013/03/12/two-contrasting-views-of-theharapan-rainforest-project-sumatra-indonesia/.

Lawlor, K., E. M. Madeira, J. Blockhus, and D. J. Ganz. 2013. Community participation and benefits in REDD+: a review of initial outcomes and lessons. Forests 4(2):296-318. http://dx.doi. org/10.3390/f4020296

Lund, J. F., E. Sungusia, M. B. Mabele, and A. Scheba. 2017. Promising change, delivering continuity: REDD+ as conservation fad. World Development 89:124-139. http://dx.doi. org/10.1016/j.worlddev.2016.08.005

Luttrell, C., L. Loft, M. F. Gebara, D. Kweka, M. Brockhaus, A. Angelsen, and W. D. Sunderlin. 2013. Who should benefit from REDD+? Rationales and realities. Ecology and Society 18(4):52. http://dx.doi.org/10.5751/ES-05834-180452

Luttrell, C., I. A. P. Resosudarmo, E. Muharrom, M. Brockhaus, and F. Seymour. 2014. The political context of REDD+ in Indonesia: constituencies for change. Environmental Science and Policy 35:67-75. http://dx.doi.org/10.1016/j.envsci.2012.10.001

Mabele, M. B., and A. Scheba. 2016. Why REDD will fail. International Forestry Review 18(3):384-386. https://doi. org/10.1505/146554816819501664

Margono, B. A., P. V. Potapov, S. Turubanova, F. Stolle, and M. C. Hansen. 2014. Primary forest cover loss in Indonesia over 2000-2012. Nature Climate Change 4:730-735. http://dx.doi. org/10.1038/nclimate2277

Margono, B. A., S. Turubanova, I. Zhuravleva, P. Potapov, A. Tyukavina, A. Baccini, S. Goetz, and M. C. Hansen. 2012. Mapping and monitoring deforestation and forest degradation in Sumatra (Indonesia) using Landsat time series data sets from 1990 to 2010. Environmental Research Letters 7(3):34010. http://dx.doi. org/10.1088/1748-9326/7/3/034010

Marthy, W., Y. Clough, and T. Tscharntke. 2016. Assessing the biodiversity value of degraded lowland forest in Sumatra, Indonesia. Kukila 19(1):1-20.

Mattangkilang, T. 2013. 'Protected' forest in North Kalimantan turned into plantations, settlements: officials. 12 March. Jakarta Globe. [online] URL: http://jakartaglobe.id/news/protectedforest-in-north-kalimantan-turned-into-plantations-settlementsofficials/

Melo, I., E. Turnhout, and B. Arts. 2014. Integrating multiple benefits in market-based climate mitigation schemes: the case of the climate, community and biodiversity certification scheme. Environmental Science and Policy 35:49-56. http://dx.doi. org/10.1016/j.envsci.2013.02.010

Minang, P. A., M. Van Noordwijk, L. A. Duguma, D. Alemagi, T. H. Do, F. Bernard, P. Agung, V. Robiglio, D. Catacutan, S. Suyanto, A. Armas, C. Silva Aguad, M. Feudjio, G. Galudra, R. Maryani, D. White, A. Widayati, E. Kahurani, S. Namirembe, and B. Leimona. 2014. REDD+ readiness progress across countries: time for reconsideration. Climate Policy 14(6):685-708. http://dx.doi.org/10.1080/14693062.2014.905822

Molnar, A., S. J. Scherr, and A. Khare. 2004. Who conserves the world's forests?: A new assessment of conservation and investment trends. Forest Trends, Washington, D.C., USA. [online] URL: http://www.forest-trends.org/documents/files/doc 163.pdf

Murdiyarso, D., S. Dewi, D. Lawrence, and F. Seymour. 2011. Indonesia's forest moratorium: a stepping stone to better forest governance? Center for International Forest Research, Bogor, Indonesia. [online] URL: https://www.cifor.org/publications/ pdf files/WPapers/WP-76Murdiyarso.pdf

Murray, J. P., R. Grenyer, S. Wunder, N. Raes, and J. P. G. Jones. 2014. Can REDD+ deliver biodiversity co-benefits in Indonesia? 
Pages 442-443 in E. O. Sills, S. Atmadja, Sassi, C. de A. E. Duchelle, D. Kweka, I. A. P. Resosudarmo, and W. D. Sunderlin, editors. REDD+ on the ground: a case book of subnational initiatives across the globe. Center for International Forestry Research, Bogor, Indonesia. [online] URL: http://www.cifor.org/ redd-case-book/part-3-synthesis/redd-ground-global-insights-localcontexts/\#box-1

Naughton-Treves, L., and C. Day. 2012. Lessons about land tenure, forest governance and REDD+: case studies from Africa, Asia and Latin America. UW-Madison Land Tenure Center, Madison, Wisconsin, USA. [online] URL: https://www.nelson.wisc.edu/ltc/ docs/Lessons-about-Land-Tenure-Forest-Governance-and-REDD. pdf

Norman, M., and S. Nakhooda. 2015. The state of REDD+ finance. Center for Global Development, Washington, D.C., USA. [online] URL: https://www.cgdev.org/sites/default/files/ CGD-Norman-Nakhooda-Climate-Forests-5-REDD-Finance.pdf http:// dx.doi.org/10.2139/ssrn.2622743

Ochieng, R. M., I. J. Visseren-Hamakers, B. Arts, M. Brockhaus, and M. Herold. 2016. Institutional effectiveness of REDD+ MRV: countries progress in implementing technical guidelines and good governance requirements. Environmental Science and Policy 61:42-52. http://dx.doi.org/10.1016/j.envsci.2016.03.018

Page, S. E., J. O. Rieley, and C. J. Banks. 2011. Global and regional importance of the tropical peatland carbon pool. Global Change Biology 17(2):798-818. http://dx.doi.org/10.1111/j.1365-2486.2010.02279. $\underline{\mathrm{X}}$

Pagiola, S., and G. Platais. 2002. Payments for environmental services. Environment Strategy Notes No. 3 May. [online] URL: https://vtechworks.lib.vt.edu/bitstream/handle/10919/66998/2496 Pagiola2002 PES EnvStrategyNote32002.pdf?sequence=1

Panfil, S. N., and C. A. Harvey. 2015. REDD+ and biodiversity conservation: a review of the biodiversity goals, monitoring methods, and impacts of $80 \mathrm{REDD}+$ projects. Conservation Letters 9:143-150. http://dx.doi.org/10.1111/conl.12188

Parlina, I. 2015. RI-Norway agree to continue REDD+. 15 April. Jakarta Post. [online] URL: http://www.thejakartapost.com/ news/2015/04/15/ri-norway-agree-continue-redd.html

Pasgaard, M., Z. Sun, D. Müller, and O. Mertz. 2016. Challenges and opportunities for REDD+: a reality check from perspectives of effectiveness, efficiency and equity. Environmental Science and Policy 63:161-169. http://dx.doi.org/10.1016/j.envsci.2016.05.021

Pelletier, J., and S. J. Goetz. 2015. Baseline data on forest loss and associated uncertainty: advances in national forest monitoring. Environmental Research Letters 10(2):21001. http://dx.doi. org/10.1088/1748-9326/10/2/021001

Peskett, L., K. Schreckenberg, and J. Brown. 2011a. Institutional approaches for carbon financing in the forest sector: learning lessons for REDD+ from forest carbon projects in Uganda. Environmental Science and Policy 14(2):216-229. https://doi. org/10.1016/j.envsci.2010.10.004

Peskett, L., B. Vickers, and K. Graham. 2011b. Equity issues in $R E D D+$. Working paper produced for the project: "Safeguarding local equity as global values of ecosystem services rise." Overseas
Development Institute, Washington, D.C., USA. [online] URL: https://theredddesk.org/sites/default/files/resources/pdf/2012/ equity issues in redd.pdf

Phelps, J., E. L. Webb, and A. Agrawal. 2010. Does REDD+ threaten to recentralize forest governance? Science 328 (5976):312-313. http://dx.doi.org/10.1126/science.1187774

Phelps, J., E. L. Webb, and L. P. Koh. 2011. Risky business: an uncertain future for biodiversity conservation finance through REDD+. Conservation Letters 4(2):88-94. http://dx.doi. org/10.1111/j.1755-263X.2010.00155.X

Pratihast, A. K., M. Herold, V. De Sy, D. Murdiyarso, and M. Skutsch. 2013. Linking community-based and national REDD+ monitoring: a review of the potential. Carbon Management 4 (1):91-104. http://dx.doi.org/10.4155/cmt.12.75

Rands, M. R., W. M. Adams, L. Bennun, S. H. Butchart, A. Clements, D. Coomes, A. Entwistle, I. Hodge, V. Kapos, J. P. Scharlemann, W. J. Sutherland, and B. Vira. 2010. Biodiversity conservation: challenges beyond 2010. Science 329(5997):1298-1303. http://dx.doi.org/10.1126/science.1189138

Redford, K. H., C. Padoch, and T. Sunderland. 2013. Fads, funding, and forgetting in three decades of conservation. Conservation Biology 27(3):437-438. http://dx.doi.org/10.1111/ cobi. 12071

Resosudarmo, I. A. P., S. Atmadja, A. D. Ekaputri, D. Y. Intarini, Y. Indriatmoko, and P. Astri. 2014. Does tenure security lead to REDD+ project effectiveness? Reflections from five emerging sites in Indonesia. World Development 55:68-83. http://dx.doi. org/10.1016/j.worlddev.2013.01.015

Santosa, M. A., J. Khatarina, and A. S. Suwana. 2013. The progress on governing REDD+ in Indonesia. International Journal of Rural Law and Policy. http://dx.doi.org/10.5130/ijrlp. i1.2013.3356

Schroeder, H., and C. McDermott. 2014. Beyond carbon: enabling justice and equity in REDD+ across levels of governance. Ecology and Society 19(1):31. http://dx.doi. org/10.5751/ES-06537-190131

Schusler, T. M., J. D. Decker, and M. J. Pfeffer. 2003. Social learning for collaborative natural resource management. Society and Natural Resources 16(4):309-326. https://doi. org/10.1080/08941920390178874

SCS Global Services (SCS). 2013. Verification report for the Rimba Raya Biodiversity Reserve Project. Infinite Earth, Hong Kong. [online] URL: http://www.vcsprojectdatabase.org/services/ publicViewServices/downloadDocumentById/12763

Silalahi, M., and D. Erwin. 2015. Collaborative conflict management on ecosystem restoration concession: lessons learnt from Harapan Rainforest Jambi-South Sumatra-Indonesia. Forest Research 4(1):134. http://dx.doi.org/10.4172/2168-9776.1000134

Sills, E. O., S. S. Atmadja, C. de Sassi, A. E. Duchelle, D. L. Kweka, I. A. P. Resosudarmo, and W. D. Sunderlin. 2014. REDD+on the ground: a case book of subnational initiatives across the globe. Center for International Forestry Research, Bogor, Indonesia. [online] URL: https://www.cifor.org/library/5202/redd-on-theground-a-case-book-of-subnational-initiatives-across-the-globe/ 
Steni, B., and N. Hadad. 2012. REDD+ safeguards in Indonesia. Bank Information Center, Washington, D.C., USA. [online] URL: $\underline{\text { https://theredddesk.org/sites/default/files/resources/pdf/2012/ }}$ steni_redd_safeguards_in_indonesia.pdf http://dx.doi.org/10.2139/ $\underline{s s r n .2203191}$

Stevens, C., R. Winterbottom, J. Springer, and K. Reytar. 2014. Securing rights, combating climate change: how strengthening community forest rights mitigates climate change. World Resources Institute, Washington, D.C., USA. [online] URL: https://www. wri.org/sites/default/files/securingrights-full-report-english.pdf

Streck, C. 2012. Financing REDD+: matching needs and ends. Current Opinion in Environmental Sustainability 4(6):628-637. http://dx.doi.org/10.1016/j.cosust.2012.10.001

Sunderlin, W. D., A. D. Ekaputri, E. O. Sills, A. E. Duchelle, D. Kweka, R. Diprose, N. Doggart, S. Ball, R. Lima, A. Enright, J. Torres, H. Hartanto, and A. Toniolo. 2014a. The challenge of establishing REDD+ on the ground: insights from 23 subnational initiatives in six countries. Center for International Forestry Research, Bogor, Indonesia. [online] URL: https://theredddesk. org/sites/default/files/resources/pdf/challenge of establishing_redd on the ground.pdf

Sunderlin, W. D., A. M. Larson, A. E. Duchelle, I. A. P. Resosudarmo, T. B. Huynh, A. Awono, and T. Dokken. $2014 b$. How are REDD+ proponents addressing tenure problems? Evidence from Brazil, Cameroon, Tanzania, Indonesia, and Vietnam. World Development 55:37-52. http://dx.doi.org/10.1016/ j.worlddev.2013.01.013

Turnhout, E., A. Gupta, J. Weatherley-Singh, M. J. Vijge, J. De Koning, I. J. Visseren-Hamakers, M. Herold, and M. Lederer. 2017. Envisioning REDD+ in a post-Paris era: between evolving expectations and current practice. WIRES Climate Change 8(1). http://dx.doi.org/10.1002/wcc.425

UN REDD Programme. 2011. Indigenous peoples and the UNREDD Programme: an overview. UN REDD Programme, Geneva, Switzerland. [online] URL: http://www.un.org/esa/ socdev/unpfii/documents/EGM IPF UNREDD.doc

United Nations Framework Convention on Climate Change (UNFCCC). 2010. National greenhouse gas inventory data for the period 1990-2008. > United Nations, Geneva, Switzerland. http://unfccc.int/resource/docs/2010/sbi/eng/18.pdf

UN-REDD Programme. 2013. Final evaluation of the UN-REDD Programme in Indonesia. United Nations REDD Programme, Geneva, Switzerland. [online] URL: https://www.unredd.net/ documents/un-redd-partner-countries-181/asia-the-pacific-333/ap-partner-countries/indonesia-187/15077-final-evaluation-of-theun-redd-programme-in-indonesia.html?path=un-redd-partnercountries-181/asia-the-pacific-333/a-p-partner-countries/indonesia-187

Uryu, Y., E. Putrastuti, Y. Laumonier, S. Sunarto, A. Budiman, K. Yulianto, A. Sudibyo, O. Hadian, D. A. Kosasih, and M. Stüwe. 2010. Sumatra's forests, their wildlife and the climatewindows in time: 1985, 1990, 2000 and 2009. A quantitative assessment of some of Sumatra's natural resources submitted as technical report by invitation to the National Forestry Council (DKN) and to the National Development Planning Agency (BAPPENAS) of Indonesia. WWF-Indonesia, Jakarta,
Indonesia. [online] URL: http://awsassets.wwf.or.id/downloads/ wwf_indonesia_2010 sumatran_forests_wildlife_climate_report for $\mathrm{dkn}$ bappenas.pdf

van der Werf, G. R., D. C. Morton, R. S. DeFries, J. G. Olivier, P. S. Kasibhatla, R. B. Jackson, G. J. Collatz, and J. T. Randerson. 2009. CO2 emissions from forest loss. Nature Geoscience 2 (11):737-738. http://dx.doi.org/10.1038/ngeo671

van Kooten, G. C., T. N. Bogle, and F. P. de Vries. 2015. Forest carbon offsets revisited: shedding light on dark woods. Forest Science 61(2):370-380. https://doi.org/10.5849/forsci.13-183

van Kooten, G. C., and C. M. T. Johnston. 2016. The economics of forest carbon offsets. Annual Review of Resource Economics 8:227-246. http://dx.doi.org/10.1146/annurev-resource-100815-095548

Vijge, M. J., M. Brockhaus, M. Di Gregorio, and E. Muharrom. 2016. Framing national REDD+ benefits, monitoring, governance and finance: a comparative analysis of seven countries. Global Environmental Change 39:57-68. http://dx.doi. org/10.1016/j.gloenvcha.2016.04.002

Virah-Sawmy, M., J. Stoklosa, and J. Ebeling. 2015. A probabilistic scenario approach for developing improved Reduced Emissions from Deforestation and Degradation (REDD+) baselines. Global Ecology and Conservation 4:602-613. http://dx.doi.org/10.1016/j.gecco.2015.10.001

Walsh, T. A., Y. Asmui, Y. Hidayanto, and A. B. Utomo. 2012. Supporting ecosystem restoration concessions in Indonesia's production forests: a review of the licensing framework 2004-2012. Climate and Land Use Alliance, San Francisco, California, USA.

Well, M., and A. Carrapatoso. 2016. REDD+ finance: policy making in the context of fragmented institutions. Climate Policy 6:687-707. http://dx.doi.org/10.1080/14693062.2016.1202096

Yasmi, Y., G. Z. Anshari, H. Komarudin, and S. Alqadri. 2006. Stakeholder conflicts and forest decentralization policies in West Kalimantan: their dynamics and implications for future forest management. Forests, Trees and Livelihoods 16(2):167-180. http:// dx.doi.org/10.1080/14728028.2006.9752554

Yu, Z., D. W. Beilman, S. Frolking, G. M. MacDonald, N. T. Roulet, P. Camill, and D. J. Charman. 2011. Peatlands and their role in the global carbon cycle. Eos, Transactions American Geophysical Union 92(12):97-98. http://dx.doi.org/10.1029/2011E0120001

Yuliani, L., Y. Indriatmoko, A. Salim, I. Z. Farid, M. Muhajir, L. B. Prasetyo, and V. Heri. 2010. Biofuel policies and their impact on local people and biodiversity: a case study from Danau Sentarum. Borneo Research Bulletin 41:109-144. 